University of Chicago Law School

Chicago Unbound

Journal Articles

Faculty Scholarship

1997

\title{
Parol Evidence Rule, the Plain Meaning Rule, and the Principles of Contractual Interpretation
}

Eric A. Posner

Follow this and additional works at: https://chicagounbound.uchicago.edu/journal_articles

Part of the Law Commons

\section{Recommended Citation}

Eric Posner, "Parol Evidence Rule, the Plain Meaning Rule, and the Principles of Contractual Interpretation," 146 University of Pennsylvania Law Review 533 (1997).

This Article is brought to you for free and open access by the Faculty Scholarship at Chicago Unbound. It has been accepted for inclusion in Journal Articles by an authorized administrator of Chicago Unbound. For more information, please contact unbound@law.uchicago.edu. 


\title{
ESSAY
}

THE PAROL EVIDENCE RULE, THE PLAIN MEANING RULE, AND THE PRINCIPLES OF CONTRACTUAL INTERPRETATION

\author{
ERIC A. POSNER $†$
}

\section{INTRODUCTION}

Most commentators believe that when a contract's terms specify the obligations of the parties in the case of some contingency, and that contingency occurs, a court should, barring procedural irregularities, enforce the terms. Much scholarship has focused on what courts should do when the terms are silent with respect to a contingency. When such a "gap" in the contract exists, this scholarship argues that the court should enforce a "gap-filling rule" or "default rule," which allocates obligations in such a way that either maximizes the contract's ex ante value or provides appropriate ex ante incentives to disclose information. Little work, however, deals with how the court should decide whether a gap exists in the first place.

Analysis of this issue requires consideration of the ways that courts can weigh different kinds of evidence, such as the final writing (if any), earlier oral or written negotiations, trade custom, and course of dealing after the contract is signed. In theory, courts could weigh evidence in whichever way seems to produce the most plausible result, or general rules could direct courts to put more weight on some kinds of evidence than on others. In fact, such general rules do exist. This Essay focuses on these rules of contractual interpretation, and the parol evidence rule in particular.

The parol evidence rule deals with a common contractual situation: where initial negotiations, in which preliminary oral or written promises are exchanged, conclude with a writing that appears to em-

† Assistant Professor of Law, University of Pennsylvania. My thanks to Lisa Bernstein, Rich Hynes, Bruce Johnson, Jason Johnston, Randy Picker, and an audience at the George Mason Law School, and particularly to Richard Craswell, whose comments were extensive and very helpful. Also thanks to Andrew Gallo and Brett Goldblatt for valuable research assistance. 
body the entire agreement. The question is whether the court's interpretation of the contract should rely at all on evidence related to the earlier negotiations, known as "extrinsic evidence," or should rely entirely on the writing.

Two stylized, polar positions can be distinguished. Under what I will call the "hard-PER," the court generally excludes extrinsic evidence and relies entirely on the writing. Under the "soft-PER," the court gives weight both to the writing and to the extrinsic evidence. There is a division among courts between those whose approaches resemble hard-PER and those whose approaches resemble soft-PER. Part I of this Essay discusses these approaches. Part II provides an analysis of the stylized hard- and soft-PERs, and discusses the ways in which these approaches may be implemented as legal rules both separately and in combination. Part II also discusses the plain meaning rule and other rules of interpretation as they relate to recurrent transactions, such as form contracts, consumer transactions, collective bargaining agreements, and long-term contracts. Part III examines Corbin's influential argument about the parol evidence rule.

The Essay lays out systematically the arguments in favor of the two different conceptions of the parol evidence rule. These arguments stress the costs to the parties of using a writing to inform courts of their contract, and the danger of judicial error. The hard- and softPERs respond to these problems in complex ways, and with varying degrees of success.

\section{The Parol Evidence Rule}

Most courts would subscribe to something close to the following statement of the parol evidence rule: A court will refuse to use evidence of the parties' prior negotiations in order to interpret a written contract unless the writing is (1) incomplete, (2) ambiguous, or (3) the product of fraud, mistake, or a similar bargaining defect. ${ }^{1}$

The rule is susceptible to hard and soft interpretations in several ways, each of which turns on the use of extrinsic evidence to determine whether any of the exceptions apply. First, consider the com-

${ }^{1}$ Purists will object that I conflate the plain meaning rule, which I treat as exception two, and the parol evidence rule. As far as I can tell, nothing turns on this distinction, and my version avoids needless complexities. Because both the parol evidence rule and the plain meaning rule concern the same issue-under what circumstances extrinsic evidence can be used to supplement a writing-they are best analyzed together. Courts and commentators often treat the two together, but sometimes do not. 
pleteness exception. The harder courts declare a writing complete if it looks complete "on its face." Writings generally look complete if they are long and detailed, or at least contain unconditional language, cover many contingencies, or at least the most important contingencies, and contain a clause, such as a merger clause, which says that the contract is complete. ${ }^{2}$ The softer courts declare a writing complete only if the extrinsic evidence supports that determination. In theory, this means that a court looks for extrinsic evidence that suggests that the writing is not complete, such as an oral statement that the writing is just a memorandum. If the court finds no such evidence, no extrinsic evidence is admitted. In some cases, this procedure may result in the exclusion of relevant extrinsic evidence. In practice, however, courts adopting this soft version of the completeness exception generally admit all relevant extrinsic evidence, because any inconsistent extrinsic evidence suggests (however indirectly) that the contract is incomplete, and any consistent extrinsic evidence that might be excluded would not affect the interpretation of the contract anyway. ${ }^{3}$

A similar point can be made about the ambiguity exception. The harder courts consider a writing ambiguous if it looks ambiguous "on its face." A contract is facially ambiguous when the writing has conflicting terms or no provision relating to the contingency under which the dispute arises. In contrast, the softer courts decide whether a writing is ambiguous by looking at extrinsic evidence. Even if the writing has no apparently conflicting terms, extrinsic evidence may indicate that the parties agreed on terms that conflict with the written terms. This conflict creates an ambiguity that requires admission of the extrinsic evidence. In contrast, if the extrinsic evidence does not conflict with the writing, it is not admissible, but its admission would make no difference, anyway. Again, the soft version of the ambiguity exception for the most part allows courts to consider any relevant extrinsic evidence. ${ }^{4}$

${ }^{2}$ See E. ALLAN FARNSWORTH, CONTRACTS $\$ 7.3$, at 474 (2d ed. 1990) ("Many courts, particularly in cases decided in the first half of this century, have agreed that .... [i]f, on its face, the agreement appears to be completely integrated, the court should simply accept that this is so.").

${ }^{3}$ This is an old point. See 4 SAMUEL Williston, WiLuISTON ON CONTRACTS $\S 633$, at 1014 (3d ed. 1961); see also John E. Murray, Jr., The Parol Evidence Process and Standardized Agreements Under the Restatement (Second) of Contracts, 123 U. PA. L. REV. 1342, 1357 (1975).

1 Under another formulation, if "the language of a contract, in the light of all the circumstances, is 'fairly susceptible of either one of the two interpretations contended 
The fraud exception presents a difficulty for the harder courts because one cannot read fraud off a contract's face; one must look at extrinsic evidence in response to an allegation of fraud. Once one looks at extrinsic evidence for fraud, however, it is easy for a party to gain admission of all extrinsic evidence. The party alleges that the promisor fraudulently violated a pre-writing promise, which induced him or her to sign the writing. Although in theory it is harder to prove promissory fraud than to prove breach of contract, ${ }^{5}$ in practice the distinctions between the two causes of action break down. The fraud exception swallows the parol evidence rule. ${ }^{6}$ Harder courts resist this outcome by distinguishing two sorts of promissory fraud, "fraud in the inducement," which refers to the use of fraudulent promises, and "fraud in the execution," which refers to the use of a false writing such as a forgery, and admitting extrinsic evidence only to show fraud in the execution. Hard courts also sometimes limit the fraud exception by restricting its use to cases where the allegedly fraudulent promise does not directly contradict a promise contained in the writing.

An example will clarify the relationship between the different versions of the parol evidence rule. Suppose that Seller and Buyer sign a written contract for sale of a used automobile, that is detailed and looks complete, but does not contain a merger clause. Before the writing is signed, Seller states in response to Buyer's query that the carburetor is in fine shape. The writing contains many provisions describing the parties' obligations, but does not contain a provision that guarantees the quality of the carburetor. In fact, the carburetor is in poor shape.

Under hard-PER, Buyer would have difficulty convincing a court to take account of the oral representation for the following reasons: First, the contract appears complete "on its face" because it is detailed

for ...,' extrinsic evidence relevant to prove either of such meanings is admissible." Pacific Gas \& Elec. Co. v. G.W. Thomas Drayage \& Rigging Co., 442 P.2d 641, 646 (Cal. 1968) (en banc) (omission in original) (citations omitted).

${ }^{5}$ Fraud requires proof that the promisor intended to break the promise at the time that it was made; ordinary breach of contract requires no such showing. Fraud claims allow the promisee to obtain reliance damages; contract claims allow expectation damages. See, e.g., Lipsit v. Leonard, 315 A.2d 25, 28-29 (N.J. 1974).

6 The problem is reproduced when courts allow promissory estoppel claims to circumvent the parol evidence rule. For a discussion, see Michael B. Metzger, The Parol Evidence Rule: Promissory Estoppel's Next Conquest?, 36 VAND. L. REV. 1383, 1454-66 (1983) (explaining the advantages and disadvantages of using promissory estoppel in parol evidence cases). 
and refers to the most probable contingencies; second, the contract appears unambiguous "on its face" because (we assume) it contains no gaps or conflicting terms; third, the fraud claim could not plausibly allege fraud in the execution, but only fraud in the inducement. As no exceptions apply, the extrinsic evidence cannot be used to interpret the contract.

Under soft-PER, the court would more likely admit evidence of the oral representation, for any of three reasons. First, the oral representation suggests that the contract's failure to stipulate or disclaim the quality of the carburetor means that the parties failed to put a crucial part of their contract in the writing. As the writing is incomplete, the oral representation can be used to interpret the contract. Second, the oral representation conflicts with (let us suppose) a rather vague written disclaimer in the contract. Was the disclaimer intended to extend to the carburetor? The oral representation may be considered in order to resolve this ambiguity. Third, the oral representation may be considered as evidence of fraud in the inducement. Under any of the three exceptions, the extrinsic evidence of the oral representation will be admitted for the purpose of interpreting the contract. ${ }^{7}$

As noted earlier, parties can, in principle, contract out of the parol evidence rule by including a "merger" or "integration" clause. This clause typically states that courts should treat the writing as a complete embodiment of the agreement. Soft-PER and hard-PER courts approach the merger clause differently. Hard-PER directs courts to defer to the clause except when the extrinsic evidence refers to an entirely different contract-as courts sometimes say, a contract that would not naturally be joined to the contract in dispute. SoftPER directs courts to admit extrinsic evidence for the purpose of determining whether the merger clause was intended to cover the terms at issue. In the example above, a soft court could evade a merger clause by holding that the oral representation shows that the merger clause was not intended to extend to the question of warranty, that the merger clause is ambiguous (as to whether it covers only some

${ }^{7}$ As an aside, note that a contract can be either fully integrated or partially integrated. If it is fully integrated, courts may not use extrinsic evidence to vary any terms within the scope of the written agreement. If it is partially integrated, courts may use any extrinsic evidence that is consistent with the writing. See RESTATEMENT (SECOND) OF CONIRACTS $\$ 210$ (1981). The concept of partial integration reflects the idea that parties may intend their writing to cover some, but not all, terms of the contract. In practice, courts have been unable to use it in a consistent way. 
terms or all terms), or that the oral representation fraudulently induced Buyer to enter the contract, including the integration aspect of it.

The hard and soft versions of the parol evidence rule, and these various qualifications, will be discussed in greater detail later in this Essay. The reader should, for now, understand that the reality is more complex than the stylized versions of the parol evidence rule developed for the purpose of analysis. Although some jurisdictions use something like the hard-PER, ${ }^{8}$ while other jurisdictions use something like the soft-PER, ${ }^{9}$ many jurisdictions take different and often conflicting approaches to the treatment of extrinsic evidence. In some jurisdictions, for example, the courts adopt a hard attitude toward the incompleteness exception, while taking a soft attitude toward the ambiguity exception. ${ }^{10}$ In other jurisdictions, the courts do

${ }^{8}$ Relatively clear examples are Missouri, see Jake C. Byers, Inc. v. J.B.C. Invs., 834 S.W.2d 806, 814 (Mo. Ct. App. 1992) (stating that "[o] ur Supreme Court prohibits the use of extrinsic evidence to interpret an otherwise unambiguous contract"), Ohio, see Trinova Corp. v. Pilkington Bros., P.L.C., 638 N.E.2d 572, 575 (Ohio 1994) (stating that where an "agreement is complete and unambiguous on its face, parol evidence is inadmissible to show a contrary intent of the parties"), Pennsylvania, see infra note 14, and Virginia, see Pulaski Nat'l Bank v. Harrell, 123 S.E.2d 382, 387 (Va. 1962) (stating that where a written contract is "in clear and explicit terms the writing shall be the sole memorial of that contract, and it is conclusively concluded that the writing contains the whole contract").

${ }^{9}$ Relatively clear examples of states in which courts say they follow soft-PER are Alabama, see Hibbett Sporting Goods, Inc. v. Biernbaum, 375 So. 2d 431, 434 (Ala. 1979) ("Where there exists doubt that the written agreement was ever intended to reflect the full agreement of the parties, the courts of this State have not hesitated to admit contradictory parol evidence ...."), Arizona, see Darner Motor Sales, Inc. v. Universal Underwriters Ins. Co., 682 P.2d 388, 398 (Ariz. 1984) (en banc) (stating that "the interpretation of a negotiated agreement is not limited to the words set forth in the document"), California, see infra note 15, Oregon, see Abercrombie v. Hayden Corp., 883 P.2d 845, 853 (Or. 1994) ("The trial court may consider parol and other extrinsic evidence to determine whether the terms of an agreement are ambiguous."), Texas, see Johnson v. Cherry, 726 S.W.2d 4, 7 (Tex. 1987) (stating that "courts must look beyond the face of the deed to ascertain the parties' intent"), and Washington, see Emrich v. Connell, 716 P.2d 863, 866 (Wash. 1986) (en banc) ("In making this ... determination of whether the parties intended the written document to be an integration of their agreement... the trial court must hear all relevant extrinsic evidence, oral or written.").

${ }^{10}$ Two examples are Oklahoma, see Mercury Inv. Co. v. F.W. Woolworth Co., 706 P.2d 523, 529 (Okla. 1985) ("While parol testimony cannot vary, modify, or contradict the terms of the instrument, it is admissible to explain the meaning of words when there is a latent ambiguity in the written text of the agreement."), and Vermont, compare Big G Corp. v. Henry, 536 A.2d 559, 561 (Vt. 1987) (stating that a negotiable instrument with an absolute promise to pay on its face cannot be varied by extrinsic evidence), with Isbrandtsen v. North Branch Corp., 556 A.2d 81, 84 (Vt. 1988) (holding that courts may "consider the circumstances surrounding the making of the agreement" in order to determine whether an ambiguity exists). 
the opposite, adopting a soft attitude toward the incompleteness exception, while adopting a hard attitude toward the ambiguity exception. "In addition, within a single jurisdiction, the parol evidence rule may vary considerably over time. In Pennsylvania, for example, hard-PER prevailed from the $1920 \mathrm{~s}$ to the $1950 \mathrm{~s},{ }^{12}$ confusion that gradually resolved itself into soft-PER prevailed from the late 1950s through the $1970 \mathrm{~s},{ }^{13}$ and hard-PER has made a comeback in the late 1980 s and 1990s. ${ }^{14}$ In California, hard-PER prevailed until the 1960s,

"Arguably, Connecticut is an example. Compare Heyman Assocs. No. 1 v. Insurance Co., 653 A.2d 122, 133 (Conn. 1995) (forbidding admission of extrinsic evidence when the meaning of "pollutant" was plain), with Shelton Yacht \& Cabana Club, Inc. v. Suto, 188 A.2d 493, 496 (Conn. 1963) (allowing consideration of extrinsic evidence to determine whether parties intended for a writing to be complete). Goetz and Scott claim that the majority of modern courts adopt this view. See Charles J. Goetz \& Robert E. Scott, The Limits of Expanded Choice: An Analysis of the Interactions Between Express and Implied Contract Terms, 73 CAL. L. REV. 261, 309 \& n.127 (1985) (citing Mellon Bank, N.A. v. Aetna Bus. Credit, Inc., 619 F.2d 1001 (3d Cir. 1980), and four other cases). My research does not confirm their claim.

${ }^{12}$ See, e.g., Gianni v. R. Russell \& Co., 126 A. 791, 792 (Pa. 1924) ("[W] propose to stand for the integrity of written contracts."); Russell v. Sickles, $160 \mathrm{~A}$. 610, 611 (Pa. 1932) ("WW] here parties have deliberately and formally committed their engagements to writing, they cannot be permitted, by parol evidence, to vary or modify the written contract.... ."); Walker v. Saricks, 63 A.2d 9, 11 (Pa. 1949) (" [U]nless fraud, accident, or mistake be averred, the writing constitutes the agreement between the parties ...." (citation omitted)); Bardwell v. Willis Co., 100 A.2d 102, 104 (Pa. 1953) ("[P]arol evidence to vary, modify or supercede the written contract is inadmissible in evidence.").

${ }^{13}$ There were several important soft-PER cases. See Berger v. Pittsburgh Auto Equip. Co., 127 A.2d 334, 337 (Pa. 1956) (admitting evidence of pre-contractual representations that were not included in the writing); Highmont Music Corp. v. J.M. Hoffmann Co., 155 A.2d 363, 366 (Pa. 1959) (noting that a provision in a lease that tenant had inspected premises and accepted the property in its present condition did not nullify the oral misrepresentation of the landlord with respect to latent defects); Myers v. Rubin, 160 A.2d 559, 561 (Pa. 1959) (" $[\mathrm{I}] \mathrm{t}$ is established law that misrepresentation of a material fact, if relied upon by the deceived party, inducing him to enter into the contract, confers upon that party the right to nullify the agreement ...."); Greenwood v. Kadoich, 357 A.2d 604, 608 (Pa. Super. Ct. 1976) (admitting evidence of appellee's pre-contractual misrepresentation); National Bldg. Leasing v. Byler, 381 A.2d 963, 965 ( $\mathrm{Pa}$. Super. Ct. 1977) ("[E]vidence that one of the parties was induced to enter the contract through fraud or misrepresentation is not barred by the parol evidence rule."). A hard-PER case was Nicolella v. Palmer, 248 A.2d 20, 22-23 (Pa. 1968) (stating that, when a subject has been dealt with specifically in the written contract, oral agreements cannot be introduced to vary terms of the written agreement in the absence of fraud, accident, or mistake).

${ }^{14}$ See HCB Contractors v. Liberty Place Hotel Assocs., 652 A.2d 1278, 1279 (Pa. 1995) (holding that the parol evidence rule barred claim alleging false representation where that issue was specifically addressed by the written instrument). 
and soft-PER thereafter. ${ }^{15}$ In contrast, Virginia has maintained hardPER fairly consistently during the last century, with only minor variations. ${ }^{16}$ In virtually every jurisdiction, one finds irreconcilable cases, frequent changes in doctrine, confusion, and cries of despair. ${ }^{17}$

\section{ANALYSIS}

\section{A. Contract Drafting and Judicial Error}

When parties strike a deal, they usually make some effort to formulate it in a way that publicizes the bargain. Some formality, such as a handshake or a writing, makes clear to the parties involved that obligations have been exchanged. Part of the function of the formality is to signal to possible future adjudicators that the parties intend to be legally bound. To the extent that this signaling function is distinct from the value-producing exchange at the heart of the contract, formalities are costly. But the adjudicatory function served by formalities

${ }^{15}$ Compare Gardiner v. McDonogh, 81 P. 964 (Cal. 1905) (hard), and Heffner v. Gross, 178 P. 860 (Cal. 1919) (hard), with Masterson v. Sine, 436 P.2d 561 (Cal. 1968) (en banc) (soft), Pacific Gas \& Elec. Co. v. G.W. Thomas Drayage \& Rigging Co., 442 P.2d 641 (Cal. 1968) (en banc) (soft), and Delta Dynamics, Inc. v. Arioto, 446 P.2d 785 (Cal. 1968) (en banc) (soft). For a more recent soft-PER case, see Garcia v. Truck Insurance Exchange, 682 P.2d 1100 (Cal. 1984) (en banc). But see Susan J. MartinDavidson, Yes, Judge Kozinski, There Is a Parol Evidence Rule in California-the Lessons of a Pyrrhic Victory, 25 Sw. U. L. REV. 1, 9 (1995-1996) (arguing that California courts use the "many standard but incompatible formulations of the parol evidence rule ... as needed").

${ }^{16}$ See Pulaski Nat'l Bank v. Harrell, 123 S.E.2d 382, 387 (Va. 1962) (commenting on Virginia's consistent adherence to hard-PER); Amos v. Coffey, 320 S.E.2d 335, 337 (Va. 1984) (stating that " $[t]$ he parol evidence rule is a time-honored fixture in the law of this Commonwealth").

${ }^{17}$ To answer these two questions [raised by the parol evidence rule], we, in Missouri, no different than the courts in most other jurisdictions, have used a variety of principles, chosen randomly with no consistency, from the common law, the treatises of Professor[s] Williston and Corbin, and the First and Second Restatement of the Law of Contracts.... [T] he random selection of principles... has made the parol evidence rule in Missouri, no different than in most other jurisdictions, a deceptive maze rather than a workable rule.

Jake C. Byers, Inc. v. J.B.C. Invs., 834 S.W.2d 806, 811 (Mo. Ct. App. 1992); see also Betz Lab., Inc. v. Hines, 647 F.2d 402, 405 (3d Cir. 1981) ("Pennsylvania decisions on the parol evidence rule are neither clear nor consistent ...."); Arthur L. Corbin, The Interpretation of Words and the Parol Evidence Rule, 50 CORNELL L.Q. 161, 164 (19641965) (discussing the confusion of the courts); Charles T. McCormick, The Parol Evidence Rule as a Procedural Device for Control of the Jury, 41 YALE L.J. 365, 383 (1932) (referring to courts' handling of the parol evidence rule as "haphazard," "oblique," and "unsatisfactory"). 
justifies their cost. The question addressed in this section is whether and how legal rules can minimize this cost.

Suppose that Seller and Buyer conclude a contract after several days of negotiations. ${ }^{18}$ During the negotiations, Seller made many statements, including promises and disclaimers, which we shall refer to as the set $S$. The contract consists of a subset of those statements, which we shall call $C$. The statements in $C$ are all the statements in $S$ that the parties would want enforced if the enforcement mechanism were perfect. $C$ is smaller than $S$, because during the negotiations Seller makes all sorts of proposals, some of which Buyer accepts, some of which Buyer rejects, and some of which Seller withdraws before Buyer has a chance to accept or before formal conclusion of the negotiations. $C^{\prime}$ consists of the statements in $S$ that are not in $C$-the statements that were made but not put in the contract, or what I will call the "extra-contractual statements." The parties put into a writing a subset $W$ of $C$; and we call the statements that are in $C$, but not in $W$, $W^{\prime}$-namely the statements in the contract that are not put in the writing, or the "unwritten statements." $W$ is smaller than $C$ because it is costly to write down every statement in the contract and because, at some point, the marginal cost of writing down an additional statement exceeds whatever marginal benefit results from putting it in writing. ${ }^{20}$ Figure 1 illustrates the analysis. ${ }^{21}$

${ }^{18}$ Nothing in this example or any other turns on the identification of one party as Buyer and the other as Seller.

19 I use the term "unwritten" for convenience, since the parol evidence rule bars admission of even written extrinsic evidence. By "unwritten statements" I mean statements, written or not, that are not included in the writing that represents the final contract.

${ }^{20}$ For now, we assume there is no merger clause in $W$, but see infra Part II.B.

${ }^{21}$ Discussion of some complexities about the content of $W$ is deferred to Section III. In particular, the reader should note that the analysis does not deal with impliedin-fact terms of the contract-those terms the parties would want enforced, ex ante, but do not stipulate to because of transaction costs. 
[Vol. 146: 533

FIGURE 1

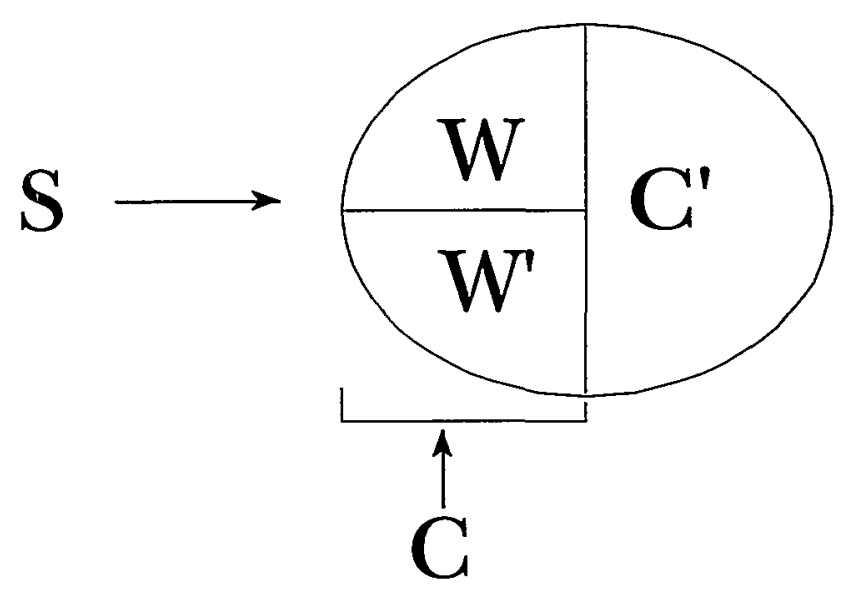

Now we can define hard-PER as a rule that tells the court to enforce all statements in $W$ and no statement in $W^{\prime}$ or $C^{\prime}$; and soft-PER as a rule that tells the court to enforce all statements in $W$ and $W^{\prime}-$ namely, $C$-but none in $C^{\prime}$. In words: Hard-PER tells the court to enforce written contractual statements, and not to enforce unwritten contractual or (written or unwritten) extra-contractual statements; soft-PER tells the court to enforce written and unwritten contractual statements, and not to enforce any extra-contractual statements.

If courts never made errors, soft-PER would clearly dominate hard-PER, because only soft-PER allows courts to evaluate all relevant evidence. The parol evidence rule makes sense only on the assumption that courts make errors, an assumption we make. Specifically, a court errs by enforcing an extra-contractual term $\left(C^{\prime}\right)$, which means failing to enforce a written or unwritten contractual term (Wor $\left.W^{\prime}\right) .^{22}$

Courts make characteristic errors under each version of the parol evidence rule. Under soft-PER, courts err by enforcing extracontractual statements with some probability greater than zero. The

${ }^{22}$ Because $C^{\prime}$ consists of all extra-contractual terms, enforcement of any of those terms constitutes failure to enforce terms in $C$. 
reason is that courts have trouble distinguishing unwritten statements that are part of the contract from unwritten statements that are not part of the contract. For the moment, we assume that courts under soft-PER enforce unwritten and written promises with an equal amount of error-proneness. Under hard-PER, courts "err" by refusing to enforce unwritten contractual statements with a probability of one. So the characteristic error under soft-PER is the court's erroneous enforcement of statements in $C^{\prime}$. The characteristic error under hard-PER is the court's refusal to enforce statements in $W^{\prime}$, which are part of the contract, even if not part of the writing. The expected loss under each rule is the product of its characteristic error and the contractual gains that are not captured as the result of error.

One might object that because soft-PER allows courts to use more information than hard-PER does, soft-PER should enable courts to produce better decisions on average even if the decisions of courts applying soft-PER will exhibit greater variance. This alternative characterization would not affect the analysis for parties that are risk-averse, since such parties are willing to pay for a reduction in variance. Even risk-neutral parties would prefer the reduction in variance because the uncertainty of the legal decision in case of a dispute would cause parties to incur greater litigation costs than they would if the legal decision could be accurately predicted.

Another relevant cost is the cost to the parties of writing down promises, including the cost of remembering to put promises in writing and checking the writing to make sure that it does not contain errors. This cost will be called the "transaction cost." Consider the case where transaction costs are zero. Under hard-PER, the parties have the choice between writing down a promise or not writing it down. If they do not write it down, it will not be enforced, and they will lose the gains from trade. If they do write it down, it will be enforced with a probability of one, supposing that the contingency it governs occurs. (Many contractual terms, of course, concern lowprobability contingencies, so the benefit of including them is probabilistic.) Because it costs the parties nothing to write down the promise, the parties include all promises in the writing, and all promises are enforced with perfect accuracy. Under soft-PER, the parties have the same choice, but now because they gain nothing from writing down the promises, they do not write down any promises. But because under soft-PER the courts erroneously enforce some extracontractual promises, and therefore fail to enforce some of the unwritten contractual promises, the full gains of trade are not realized. 
Accordingly, when transaction costs are zero, hard-PER dominates soft-PER.

When transaction costs exceed zero, the analysis becomes more complex. One must distinguish the initial decision whether to use a writing from the decision to incorporate additional promises into the writing. If the parties do not use a writing, the parol evidence rule does not apply to a dispute. Initially, we consider only cases where parties use a writing. Once they decide to use a writing, they must decide how many terms to place in the writing. It is reasonable to assume that parties will first put the most important promise (a term is just a subsidiary promise) in the writing, then the next most important, and so on, where importance is measured by how much value the promise contributes to the contract. Thus, the marginal value of adding a promise to the writing declines.

At the same time, adding a promise to the writing is costly. The reason is that the drafter must recall every promise that was made, and then must write it down in a way that is satisfactory to both parties. Because one can divide possible future states of the world into indefinitely fine partitions, even the simplest contracts would generate huge transaction costs if the parties tried to put in the writing obligations for all possible future states of the world.

Under hard-PER, the addition of a promise to the writing produces costs and gains. The cost is the transaction cost of the addition to the writing. The gain is the value of enforcement of the promise should the promisor breach. When the transaction cost of the marginal promise exceeds the marginal expected value of enforcement of that promise, the parties do not incorporate that promise in the writing.

Under soft-PER, the addition of a promise to the writing produces costs but does not produce gains. The addition of the promise to the writing is costly because the drafter incurs costs in writing down the promise. But the addition of the promise does not generate any gains, because under the extreme version of soft-PER the court does not put more weight on the written promise than on the oral promise. The court enforces either promise with the same degree of errorproneness. Because the parties gain nothing by putting the marginal promise in the writing, they do not use writings.

We can avoid this counterintuitive result by making two additional assumptions. First, the parties use writings for their own purposes as well as for legal purposes, namely, so that they can remember and refer to obligations after time has passed and memories have 
dimmed. Second, even the softest courts put more weight on written promises than on oral promises. Accordingly, it is reasonable to assume that the probability of failure to enforce an unwritten promise is greater than the probability of failure to enforce a written promise. Under these additional assumptions, one would expect parties in a soft-PER regime to put some promises in a writing, although fewer than similar parties in a hard-PER regime.

The advantage of hard-PER is that when the transaction costs are less than the value of the promise, parties will write it down and be assured of accurate enforcement. The disadvantage is that when transaction costs are greater than the value of the promise, parties will not write down the promise and the resulting failure to enforce deprives them of the promise's entire value. The advantage of soft-PER is that when transaction costs are greater than the value of the promise, so that parties do not write down the promise, the parties do not lose the full value because courts will enforce unwritten promises, albeit with some chance of error. The disadvantage of soft-PER is that when transaction costs are less than the value of the promise, parties cannot obtain the value of certain judicial enforcement by writing down the promises, because courts' willingness to enforce unwritten promises creates a risk of judicial error.

An example will clarify the discussion so far. Suppose that Buyer offers to pay Seller $\$ X$ for a widget. In this contract, there are two promises, Seller's promise to deliver the widget when Buyer transfers $\$ X$, and Seller's warranty that the widget performs certain functions. Buyer values the widget at $\$ 20$ and the warranty at $\$ 10$. The parties put the promise to deliver in the writing, and now must decide whether to put the warranty in the writing. The decision turns on whether putting the warranty in the writing reduces the chance of judicial error should a dispute arise. Under hard-PER, incorporation of the warranty into the writing increases the value of the contract to Buyer by $\$ 10((1) \$ 10-(0) \$ 10)$. Suppose that a soft-PER court would correctly enforce a written promise with probability of 0.6 and would correctly enforce an oral promise with probability of 0.2 . Incorporation of the warranty into the writing under soft-PER increases the value of the contract to Buyer by $\$ 4((0.6) \$ 10-(0.2) \$ 10)$.

Now consider three levels of transaction costs. If transaction costs are $\$ 1$, the parties under hard-PER would add the warranty to the writing, resulting in a net gain of $\$ 9$. The parties under soft-PER would add the warranty to the writing, resulting in a net gain of $\$ 3$. 
If transaction costs are $\$ 6$, the parties under hard-PER would add the warranty to the writing, resulting in a net gain of $\$ 4$. The parties under soft-PER would not add the warranty to the writing, and so would gain only $\$ 2$ from the oral warranty.

If transaction costs are $\$ 20$, the parties under hard-PER would not add the warranty to the writing, resulting in a gain of $\$ 0$. The parties under soft-PER also would not add the warranty to the writing, but would still gain $\$ 2$.

This example shows that the optimal treatment of extrinsic evidence of a promise depends on (1) the amount it would have cost the parties to add that promise to the writing (call this amount " $B$ "); and (2) the value that the promise contributes to the contract discounted by the increased probability of correct judicial enforcement should a dispute arise (call this amount " $p L$ "). When $B$ is high and $p L$ is low, the advantage belongs to soft-PER because it permits enforcement of the promise, even if not with perfect accuracy. When $B$ is low and $p L$ is high, the advantage belongs to hard-PER because it allows the parties to ensure accurate enforcement by allocating promises to the writing. In short, if $B>p L$, the court should admit the extrinsic evidence and enforce the unwritten promise; otherwise, it should exclude the evidence and decline to enforce the unwritten promise.

Having stated the general thrust of the argument, several qualifications are in order. First, it is unrealistic to assume that a court accurately estimates the parties' transaction costs and the value of the promise in question but still enforces oral promises with a high degree of error. The assumption will be dropped in a later section, where it will be shown that-in the absence of this assumption-the court's decision should be based on a general rule rather than on direct evaluation of these variables.

Second, the assumption that courts accurately enforce written promises with a probability of one under hard-PER is also false. But the analysis survives as long as one assumes that courts under hardPER enforce written promises more accurately than courts under softPER enforce written and oral promises, an assumption that is based on the premise that hard courts do not try to enforce oral promises that might be extra-contractual. ${ }^{23}$

Third, some readers might find troublesome the assumption that the parties use a writing and that the choice of whether to write down an additional promise is the subject of analysis. However, because the

${ }^{25}$ This premise is examined in more detail in Part III. 
parol evidence rule applies only if the parties use a writing, this assumption is justified. A later section of this Essay will address the decision to use a writing in the first place by considering why the parol evidence rule does not apply to oral contracts.

\section{B. The Parol Evidence Rule as a Default Rule}

When contracts do not specify the use of extrinsic evidence, there is a "gap" in the contract. Even when contracts do specify the use of extrinsic evidence through a merger clause, there is a gap in the sense that the scope of the merger clause is not self-interpreting. Courts fill in gaps through the use of default rules.

A default rule can be more or less "tailored." ${ }^{24}$ A more tailored rule (or "standard") directs a court to fill in the gap with the terms that the actual parties would have chosen had transaction costs been zero. A less tailored rule directs a court to fill in the gap with terms that the average party would have chosen if transaction costs had been zero. There has been much discussion about whether default rules should be more or less tailored, but little progress has been made at an abstract level.

For parol evidence, a highly tailored default rule makes little sense. A highly tailored rule would direct a court to admit extrinsic evidence only if the parties involved would have wanted the court to do so. The best evidence of the parties' hypothetical desires is (1) the transaction cost of adding the promise in question to the writing; and (2) the expected value that the promise would have contributed to the contract. Although it seems possible that courts could estimate the transaction costs in a rough way, two barriers stand in the way of accurate estimation of the promise's expected value.

First, there is an epistemic barrier. Suppose the parties accurately believed that the court that would decide a dispute is highly errorprone, and therefore they put most of their promises in the writing in the hope that the court would exclude extrinsic evidence. The court should then be asked to determine whether the parties had this belief. But if the parties' belief was accurate, and the court is errorprone, it is unlikely that this court could determine that the parties would have wanted, and in fact did want, the court to exclude the extrinsic evidence. As a result, the court might erroneously admit the

${ }^{24}$ See Ian Ayres \& Robert Gertner, Filling Gaps in Incomplete Contracts: An Economic Theory of Default Rules, 99 YALE L.J. 87, $91-92$ (1989) (discussing default rules for contract interpretation). 
evidence. In a phrase, it does not make sense to ask courts to determine whether parties expected them to be error-prone, because their error-proneness will prevent them from discovering the answer.

Second, there is a practical barrier. Even if an error-prone court correctly realizes that the parties would not have wanted it to admit extrinsic evidence, an untailored rule requires a court to exercise a self-discipline that is likely to be beyond it. Although juries decide many questions of fact in contract cases, judges generally have the power and obligation to interpret the contract. In interpreting the contract, judges rely on all admitted evidence. To determine whether to admit evidence under the parol evidence rule, judges first must evaluate the evidence. They cannot estimate the transaction costs the parties would have incurred to add a promise to a writing, and the expected added value of that promise, without evaluating the extrinsic evidence of that promise. But having done so and having decided to exclude the extrinsic evidence, it may be difficult for the judge to purge the extrinsic evidence's influence on his evaluation of the dispute. In contrast to procedures involving the exclusionary rules of criminal law-where the jury, as decisionmaker, does not know about evidence that the judge has excluded-a judge in a contract case must confront and evaluate evidence before excluding it.

In sum, if a court is, in fact, incompetent, then it will not be able to realize, both epistemically and practically, that the parties recognize its incompetence and would not want it to evaluate the evidence because of its incompetence. If a court is so competent that it can accurately evaluate the extrinsic evidence for the purpose of determining its admissibility, it might as well use it for the purpose of interpreting the contract.

These problems are avoided if the parol evidence default rule is untailored. By this I mean that a single parol evidence rule is applied in all contract cases. The untailored rule avoids the paradox of courts admitting or excluding evidence according to whether they think they are competent to evaluate it. Instead, courts automatically consider all extrinsic evidence if the rule is soft-PER; or they automatically exclude extrinsic evidence if the rule is hard-PER. ${ }^{25}$

${ }^{25}$ It is true that a court would have to consider extrinsic evidence before excluding it. But under untailored hard-PER, a court would refuse to consider any evidence about a promise after eliciting an admission from a party that the promise is not written. Thus, even if a court learns from the pleadings that the party claims that an extrinsic promise occurred, it would not have a chance to evaluate the plausibility of that claim. 
But, supposing one is committed to an untailored rule, should soft-PER or hard-PER be that rule? We saw before that under an untailored rule (or standard) a court should admit extrinsic evidence of an unwritten promise when the transaction cost of adding that promise to a writing exceeds the expected value of that promise. Because this standard is applied at the margin, it cannot be translated easily into a rule that applies to all promises. To see why, imagine that in a jurisdiction there are $n$ identical transactions, in which the first promise generates an expected gain of $\$ 20$, the second promise generates an expected gain of $\$ 10$, and the third promise generates an expected gain of $\$ 5$, and in each case it costs $\$ 8$ to add the promise to a writing.

Suppose further that courts under hard-PER enforce written promises with a probability of one, and unwritten promises with a probability of zero; courts under soft-PER enforce written promises with a probability of 0.7 and unwritten promises with a probability of 0.2. Under hard-PER, the parties would add the first and second promises to the writing, but not the third. The gain is $\$ 14(20+10-8$ - 8). Under soft-PER, the parties would add the first promise to the contract (because $(0.7) 20-(0.2) 20=10>8$ ), but not the second (because $(0.7) 10-(0.2) 10=5<8)$ or the third. The gain under soft$\mathrm{PER}$ is thus $\$ 9((0.7) 20+(0.2) 10+(0.2) 5-8)$. To determine whether hard-PER is globally superior to soft-PER, one would have to look at all the promises made in the average contract, take for each promise the greater of (a) the probability of enforcement if written, multiplied by the value of that promise, minus the transaction cost of adding it to a writing; or (b) the probability of enforcement if unwritten, multiplied by the value of that promise-and then sum up the relevant amount for each promise. If the sum is higher under hardPER than under soft-PER, hard-PER is globally superior.

Because of difficulties in measurement, this formula is useless for determining whether a particular jurisdiction should choose soft-PER or hard-PER as its untailored parol evidence rule. However, the formula highlights important factors. If our continuing assumption is correct, that hard-PER results in high-probability enforcement of written promises and low-probability enforcement of unwritten promises, while soft-PER results in medium-probability enforcement of both promises, then (a) declining transaction costs favor hard-PER, and (b) declining judicial competence favors hard-PER. Actually, the latter conclusion depends on an additional assumption that less competent courts enforce written promises with a high probability when 
directed by hard-PER to enforce only written promises, while more competent courts enforce unwritten promises with a higher probability than do less competent courts when permitted by soft-PER.

The importance of factors (a) and (b) becomes clear as we move to consideration of a final kind of rule. This kind of rule is neither a highly tailored nor an untailored rule, but a semi-tailored rule. Such a rule would divide contract cases into different classes, and courts would apply soft-PER to cases in some of the classes and hard-PER to cases in other classes. The classes could be based on the kind of transaction, such as sales of goods, real estate transactions, and bills and notes; or on the kind of parties, such as sophisticated parties, consumers, and lawyer-assisted parties. For a particular class, the parol evidence rule should be hard-PER when the transaction costs of writing down the typical promise in that class are low and judicial competence is low. This follows from the analysis of untailored rules, except we apply the analysis to a class of cases rather than to all the cases in a jurisdiction.

The semi-tailored rule comes at a cost, however. Before applying hard- or soft-PER, the court must classify the case before it, and may err in classification. The court might, for example, classify a consumer case as a business case and apply hard-PER when soft-PER is appropriate. This cost must be balanced against the cost of using a less tailored rule, such as global hard-PER, under which courts will not miscategorize cases but will apply hard-PER to cases for which soft-PER would be more appropriate; and against the cost of using a more tailored rule, under which courts do not miscategorize cases but will often err in their attempts to evaluate whether parties would have wanted them to exclude or admit extrinsic evidence. Because courts err in classifying cases under the semi-tailored rule, parties will err in predicting how courts will classify their case and thus will lose the benefits that otherwise would result from the enforcement of that parol evidence rule which is optimal for a given class of cases. ${ }^{26}$ Measuring these tradeoffs is beyond the competence of the observer. As discussed shortly, however, it is clear that the parol evidence regime in American law is one of semi-tailored rules.

A Note on Penalty Defaults. We have assumed that the desirable default rule is majoritarian, and that the only question is the extent of

${ }^{26}$ For a general discussion of the effect of complex rules on individual decisionmaking, see Louis Kaplow, A Model of the Optimal Complexity of Legal Rules, 11J.L. ECON. \& ORG. 150 (1995). 
tailoring. Some commentators have argued influentially in recent years that default rules sometimes should stipulate terms that the majority of parties would not want. ${ }^{27}$

One version of this argument is based on the fear that parties externalize their costs onto a subsidized court system. Suppose parties decline to put terms in a writing even though the cost of doing so is less than the court's cost of interpreting the contract ex post. Although most parties prefer soft-PER because it saves them transaction costs, courts should choose hard-PER. This argument is discussed at greater length subsequently.

Another argument in favor of penalty defaults is that they improve parties' incentives to reveal value-maximizing information to each other prior to entering a contract. This argument, which lies behind the support among many commentators for the Hadley rule, is that penalty defaults, by forcing buyers with private information to bargain for favorable terms, eliminate inefficient cross-subsidization that would otherwise result from the seller's inability to distinguish types of buyers. This kind of argument, already problematic in the Hadley case for reasons beyond the scope of this Essay, ${ }^{28}$ does not have a plausible application to the treatment of extrinsic evidence.

A Note on Merger Clauses. Contracts often contain merger clauses that direct courts not to use extrinsic evidence. Interestingly, contracts never, as far as I know, contain clauses that direct courts to rely on extrinsic evidence. The lack of such "anti-merger" clauses might be a clue that most parties would reject soft-PER-a point to which I will return later.

The problem is that it is conceivable, even likely, that the parties intend a merger clause to govern some, but not all, elements of their contractual relationship. In the classic case, the parties enter an integrated, written contract that is unrelated to a prior oral contract. Most agree that the merger clause in the later contract does not preclude enforcement of the prior contract, because parties would not discharge a contract in such an indirect way. But suppose that the prior and subsequent contracts have some elements in common.

${ }^{27}$ See Ayres \& Gertner, supra note 24 (popularizing the term "penalty default," though the basic idea goes back many years).

${ }^{28}$ See Eric A. Posner, Contract Remedies: Foreseeability, Precaution, Causation, and Mitigation, in ENCYCLOPEDIA OF LAW AND ECONOMICs (Boudewijn Bouckaert \& Gerrit De Geest eds., forthcoming 1998) (examining the weaknesses in the argument that the Hadley rule gives incentives to promisees to reveal information which would give promisors incentive to take care). 
Should the merger clause be read broadly, to govern the earlier contract, or narrowly, to govern only the later contract? ${ }^{29}$ As the contracts become more and more closely related, the question becomes harder to resolve.

Courts should approach this problem like any other contractual gap. Our previous analysis suggests, for example, that when transaction costs are low and judicial error is likely, courts should interpret merger clauses broadly. The reason is that the parties can at low cost move terms from $W^{\prime}$ to $W$, and their use of a merger clause suggests that their failure to do so was not inadvertent. If transaction costs are high and judicial error unlikely, courts should interpret the merger clause narrowly so as to include extrinsic evidence of a prior oral contract. $^{30}$ As a doctrinal matter, courts that adopt hard-PER hold that a merger clause creates a strong, sometimes conclusive, presumption that the parties intend courts not to rely on extrinsic evidence. ${ }^{31}$ Courts in soft-PER jurisdictions generally hold that a merger clause creates a rebuttable presumption that the parties intend courts not to rely on extrinsic evidence. ${ }^{32}$

Another rationale for discounting merger clauses is procedural irregularity. Sometimes merger clauses are buried in fine print. If it appears that the consumer did not consent to the merger clause, a court might reasonably use the unconscionability doctrine to avoid the merger clause and use the default analysis discussed above to fill in the resulting gap. ${ }^{33}$

${ }^{29}$ Cf. Mitchill v. Lath, 160 N.E. 646, 647 (N.Y. 1928) (holding that evidence of a prior agreement was precluded because the promise was of the sort which naturally would have been included in the final contract).

${ }^{30}$ This gives some substance to the often-invoked but vacuous principle that a court should refuse to consider extrinsic evidence of an earlier agreement because of a merger clause in a later written contract, if "the parties would ordinarily or naturally be expected to embody the [earlier] agreement ... in the [later] written agreement." Id. at 649 (Lehman, J., dissenting).

${ }_{31}$ See FARNSWORTH, supra note $2, \S 7.3$, at 476 (noting that courts have traditionally given effect to merger clauses as showing an intention that the contract be completely integrated).

${ }_{32}$ See, e.g., L.S. Heath \& Son, Inc. v. AT\&T Info. Sys., Inc., 9 F.3d 561, 569 (7th Cir. 1993) (explaining that a merger clause is strong, but not dispositive, evidence that the parties intended the writing to be complete); see also FARNSWORTH, supra note $2, \S 7.3$, at $476 \& \mathrm{n} .36$ (listing cases).

${ }^{33}$ See Richard Craswell, Property Rules and Liability Rules in Unconscionability and Related Docirines, 60 U. CHI. L. REV. 1, 57-60 (1993) (discussing the proper way for courts to address the problem of contracts which are misleading because of unfavorable terms buried in the fine print). 


\section{Doctrinal Implications of the Analysis}

No jurisdiction has a bright-line hard-PER or soft-PER. Courts might state one or the other as a general rule, but all sorts of subsidiary doctrines provide exceptions. The analysis sheds light on these exceptions by relating them to a unified conception of contractual interpretation.

By making some assumptions about the relationship among the variables identified by the model and business practices, we can make some useful, though rough, generalizations. The first assumption is that transaction costs $(B)$ are likely to be high when the parties are unsophisticated or the contract is complex. Unsophisticated parties face high transaction costs because they cannot draw upon experience in order to allocate terms among writings and because they may not know about the law. Parties to complex contracts face high transaction costs because they must remember to put a large number of terms into a writing. The second assumption is that the probability of judicial error $(p)$ is likely to be high when the contract is unconventional, because courts do a better job of enforcing terms they have seen before than terms they have not. ${ }^{34}$ These two assumptions generate the matrix displayed in Figure 2.

\section{FIGURE 2}

\begin{tabular}{|c|c|c|}
\hline & conventional & unconventional \\
\hline simple/sophisticated & $?$ & hard-PER \\
\hline complex/unsophisticated & soft-PER & $?$ \\
\hline
\end{tabular}

Figure 2 shows that when contracts are conventional and complex, soft-PER is optimal. The reason is that complexity or lack of sophistication prevents the parties from moving terms into a writing, while the conventionality of the contract suggests that judicial error will be low. When contracts are unconventional and simple, hardPER is optimal. The reason is that simplicity or sophistication sug-

${ }^{34}$ Again, these generalizations are crude, and there are objections to each. If a contract is complex, courts might have difficulty interpreting it, and thus judicial error is likely to be high. Judicial error is therefore a function of both factors, not just conventionality. Moreover, if a contract is unconventional, the transaction costs of reducing it to a writing might be high because of the lack of models or forms. Thus, transaction costs are a function of both factors, not just complexity. These complications are dealt with below. 
gests that the parties can easily move terms into a writing in anticipation of the likelihood of judicial error caused by the unconventionality of the deal. In the other two boxes, it is not clear which of the factors dominates, so one cannot say with much confidence whether hard-PER or soft-PER is likely to be superior. We can further complicate the matrix by taking into account $L$ (the value that the promise contributes to the contract), which suggests that hard-PER is likely to be superior for high-value contracts because the greater amounts at stake justify higher transaction costs. Using these considerations, we can make some general comments about recurring fact situations and doctrines relating to contractual interpretation.

\section{Ordinary Consumer Contracts}

Because these contracts are "complex" from the perspective of unsophisticated consumers, but routine and easy to understand for courts, ordinary consumer contracts are good candidates for soft-PER. That such contracts are low-value strengthens this conclusion, since it is not worth the costs for consumers to read the contracts carefully or to invest in legal advice and other sources of information in order to learn whether they should read the contracts carefully. ${ }^{35}$

That soft-PER should apply when extrinsic evidence benefits consumers, however, does not mean that soft-PER should apply when extrinsic evidence benefits sellers. Because sellers are sophisticated and because they obtain economies by formalizing their contracts, sellers have lower transaction costs than buyers do. Hard-PER, therefore, is plausibly applied against sellers who seek to have extrinsic evidence admitted for their benefit, although it may also be the case that the expected loss from judicial error is low enough that sellers, too, would not find it worthwhile to use a writing.

The larger point is that the court's approach to the buyer and seller need not be symmetrical. The court could sensibly admit extrinsic evidence that benefits buyers while excluding extrinsic evidence that benefits sellers, on the ground that sellers can put relevant promises in the writing more cheaply than can buyers. The analysis resembles the view in tort law that contributory negligence promotes

${ }^{35}$ Courts are particularly solicitous of consumers in insurance cases. See, e.g., Darner Motor Sales, Inc. v. Universal Underwriters Ins. Co., 682 P.2d 388, 401 (Ariz. 1984) (reversing lower court's summary judgment award for insurer because the nature of the transaction suggested that insured acted reasonably in not reading a particular policy provision). 
efficiency by giving the victim an incentive to take precautions when the victim is the cheaper loss-avoider.

\section{High-Value Consumer Contracts}

The case for soft-PER becomes weaker when the consumer purchases something of great value, such as a house. In such cases the expected error costs rise significantly, because (1) the goods are worth more than in ordinary consumer contracts, and (2) the contracts are less routine, thus raising the likelihood of judicial error. The second point is more likely to be true for some high-value sales, such as real estate transactions, for which markets are thin, than for others, such as automobile transactions, for which markets are thick. ${ }^{36}$ Hard-PER may appropriately encourage the consumer to hire a lawyer before making a large purchase. Alternatively, if consumers naturally hire lawyers before making a large purchase, it encourages the lawyer to put terms in the writing.

\section{Unusual but Simple Contracts}

The strongest case for hard-PER is a contract that is frequently created by sophisticated parties, simple, unconventional, and of high value. One possibility for this category is the complex financial instrument, such as the derivative. The terms of derivatives are so unusual that courts are likely to misunderstand them; yet, to sophisticated parties, the contracts are fairly simple, in the sense that there are not many contingencies to worry about and the contract can be written in a way that accounts for them. In addition, these contracts are typically of high value.

\section{Notes and Instruments}

A promissory note is a simple, highly formalized device for transferring value, but it is usually exchanged as part of an underlying contract which may be more complex. The use of a note is one way to contract around the parol evidence rule: it restricts the promisor's ability to resist paying by arguing that the contract is invalid. The parties have an incentive to use notes when they want to limit judicial involvement and judicial error. Courts, however, often admit extrin-

${ }^{36}$ Cf. Lee v. Joseph E. Seagram \& Sons, Inc., 552 F.2d 447, 451-52 (2d Cir. 1977) ("[I]ntegration is most easily inferred in the case of real estate contracts for the sale of land, ... or leases." (citations omitted)). 
sic evidence for the limited purpose of showing that the promissory note was intended to be valid only for the purpose of disbursement from a particular fund. ${ }^{37}$ This limited soft-PER exception to the hardPER rule is justified by the ease with which the existence of a fund can be proved, compared to the difficulty of showing that performance of the contract was not completed in the proper manner.

\section{Complex Business Contracts}

Another candidate for hard-PER is the complex business deal, such as the sale of a firm. Because of the large number of statements made during preliminary negotiations, the number of statements that are outside the contract $\left(C^{\prime}\right)$ is likely to be high. As a result of the idiosyncrasy of the terms, erroneous judicial enforcement of some of those statements is likely. And because of the high value of the transaction, errors in enforcement are costly. Yet, the complexity of the contract typically means that the parties face high transaction costs. Therefore, the benefits of hard-PER may not be obtainable. ${ }^{38}$

\section{Forms ${ }^{39}$}

Some courts are more willing to apply soft-PER to printed form contracts that do not permit amendment than to other kinds of contracts. This approach is consistent with our analysis. Because the forms forbid amendment, the transaction costs of putting additional terms in the writing are high. Because these form contracts are often routine, the likelihood of judicial error is low. Accordingly, soft-PER is appropriate.

${ }^{37}$ See, e.g., Mozingo v. North Carolina Nat'l Bank, 229 S.E.2d 57, 61-62 (N.C. C. App. 1976) (admitting extrinsic evidence to show the agreed upon method of payment on a note).

ss "In more complex situations, in which customary business practice may be more varied, an oral agreement can be treated as separate and independent of the written agreement even though the written contract contains a strong integration clause." Lee, 552 F.2d at 451-52. The point is that, because they are simpler, real estate transactions have lower transaction costs than complex business transactions. See also Abercrombie v. Hayden Corp., 883 P.2d 845, 852-53 (Or. 1994) (holding that extrinsic evidence of a promise to extend a closing date was improperly admitted to vary the terms of a quitclaim deed). The court in Abercrombie purported to find no ambiguity in the deed, even in light of the extrinsic evidence, but one suspects that it feared that the contrary holding would destroy the utility of the quitclaim deed for quieting title.

${ }^{59}$ This and the next two categories were suggested by Richard Craswell. 


\section{Terms That Are Central to the Contract}

Courts are often reluctant to admit extrinsic evidence to vary written terms that are central to the contract. If the term is central, then the expected cost of judicial error is likely to be high. In addition, the transaction cost of moving it is likely to be low, because the parties are unlikely to overlook it. Thus, a harder version of the parol evidence rule is justified.

\section{Failure to Use a Writing}

Does the analysis have implications for oral contracts? The parol evidence rule could apply to the oral contract by barring admission of evidence of promises that precede the final (oral) agreement. But the parties' failure to use a writing suggests (1) that the parties do not believe that the expected costs of judicial error are high, because otherwise they would use a writing to constrain judicial interpretation, and (2) that the transaction costs of using a writing are high relative to the gains from more accurate enforcement. Most of the transaction costs involved in writing contracts do not result from the physical act of the writing but from the difficulty of formalizing a series of negotiations without creating errors. These costs remain present when parties seek to come to a final oral agreement that concludes earlier negotiations. If the costs of using a writing are high relative to the gains, the costs of formally repeating earlier promises in the final oral agreement are also likely to be high relative to any gains. Therefore, much of the value of the contract would be contained in earlier promises, and hard-PER would prevent gains obtainable under softPER.

\section{Long-Term Contracts}

Long-term or relational contracts are contracts whose terms are underspecified because the parties cannot anticipate contingencies with much accuracy and so prefer to leave the trading relationship open to continuous renegotiation and revision. Because the terms of the relationship are expected to develop over time, the parties cannot at low cost commit the entire agreement to a writing. Transaction costs are high, but at the same time the cost of judicial error is high 
because of the large number of statements in $C^{\prime}$ and their idiosyncrasy. Thus, it is not clear whether hard-PER or soft-PER is superior. ${ }^{40}$

\section{Collective Bargaining Agreements}

Collective bargaining agreements are complex, because they cover every aspect of the employment relationship. However, both employers and unions are usually sophisticated. In addition, judicial error is likely to be common, because collective bargaining agreements reflect the idiosyncrasies of the local workplace. The cost of error is likely to be high also, because collective bargaining agreements affect many people and last years or decades. Stressing these last two factors, Judge Easterbrook argues that courts should adopt a restrictive attitude toward admission of parol evidence for the purpose of interpreting collective bargaining agreements. ${ }^{41}$ Whether these costs outweigh the transaction costs of putting the full contract into the writing, however, is difficult to determine.

\section{The Interpretation of Contracts Against the Drafter}

This principle reflects an assumption that the drafter can more cheaply ensure that the contract is reflected in the writing than the other party can. When the drafter seeks admission of extrinsic evidence that benefits it, this principle acts as hard-PER; when the drafter seeks to resist admission of extrinsic evidence that benefits the other party, the principle acts as soft-PER.

\section{Course of Dealing, Course of Performance, and Trade Usage}

Courts generally admit evidence of the parties' prior dealings, of their dealings after the contract has been entered, and of trade usage. ${ }^{42}$ Commentators often argue that the distinction between these kinds of evidence and the extrinsic evidence barred by the parol evidence rule is arbitrary. But there is a reason for this distinction: Course of dealing and course of performance leave a trail of receipts

${ }^{40}$ Cf. Goetz \& Scott, supra note 11 , at 317-20 (discussing the interpretation of relational contracts).

${ }^{41}$ See Bidlack v. Wheelabrator Corp., 993 F.2d 603, 618-19 (7th Cir. 1993) (en banc) (Easterbrook, J., dissenting) (arguing that parol evidence should rarely be allowed in labor contract cases because of the desire for flexibility in these sweeping, long-term contracts, the low reliability of parol evidence that may be decades old, and the chilling effect that potential parol evidence surprises may have on negotiations).

${ }^{42}$ This rule is codified in U.C.C. $\$ 2-202$ (a) (1990). 
and other documents, and events to which disinterested witnesses can testify. Trade usage can be determined through the publications of trade associations and the testimony of uninvolved industry actors. In contrast, promises made during negotiations are asserted by and frequently known only by interested parties. Because admission of extrinsic evidence regarding course of dealing, course of performance, and trade usage is less likely than admission of other forms of extrinsic evidence to result in judicial error, a more permissive stance toward the former is justified. ${ }^{43}$

\section{Ambiguity Versus Completeness}

As noted earlier, courts sometimes admit extrinsic evidence for the purpose of interpreting ambiguous contracts but not for the purpose of interpreting incomplete contracts, and vice versa. The different treatment of the different circumstances assumes that transaction costs and error costs differ systematically when ambiguity arises and when incompleteness arises. Courts never justify this assumption, and the cases give the impression that courts veer to one extreme to avoid the unpleasant consequences that would result from rigorous adherence to the other.

A rationale can, however, be found in the analysis of Goetz and Scott. They argue that courts should take a soft approach toward incompleteness and a hard approach toward ambiguity. ${ }^{44}$ The reason for the soft approach toward incompleteness is that parties frequently leave out customary terms when they draft contracts. If courts routinely excluded evidence of customary terms, either they would enforce contracts inaccurately or they would force parties to incur substantial costs in producing more complete contracts. The reason

19 Recent judicial approval of this distinction can be found in AM International, Inc. v. Graphic Management Associates, Inc., 44 F.3d 572, 575 (7th Cir. 1995), which distinguishes between objective and subjective evidence of contractual ambiguity. Bernstein criticizes admission of evidence regarding trade usage, course of performance, and course of dealing, arguing that basing legal obligations on such evidence interferes with contracting by (1) preventing parties from relying on the extra-legal promises that are essential to value-maximizing business relations, and (2) forcing them to incur high transaction costs to contract out of the rule (presumably by stating in their contracts that trade usage, course of performance, and course of dealing are not legally relevant). See Lisa Bernstein, Merchant Law in a Merchant Court: Rethinking the Code's Search for Immanent Business Norms, 144 U. PA. L. REv. 1765, 1796-815 (1996) (discussing the U.C.C.'s treatment of trade usage, course of performance, and course of dealing). Bernstein's formalism relies on empirical assumptions on which I take no position.

11 See Goetz \& Scott, supra note 11, at 313-16. 
for the hard approach toward ambiguity, which is a version of the penalty default argument, is that parties should be encouraged to contract out of custom, because externalities that arise in connection with the evolution of custom cause custom to lag behind technological change. If courts routinely admitted evidence of customary terms, parties would have no incentive to evaluate and modify custom in response to technological change.

The problem with Goetz and Scott's analysis is that the assumptions of each argument conflict. The completeness argument assumes that courts accurately discover customary terms and that high transaction costs prevent parties from incorporating these terms directly into the writing. The ambiguity argument assumes that courts fail to recognize the inadequacies of customary terms and that low transaction costs enable parties to contract around customary terms. Because the ambiguity rules and completeness rules overlap so much, with both of them referring essentially to the use of extrinsic evidence to interpret writings that do not allocate obligations in sufficient detail, the use of different assumptions for each argument is not justified. This can be seen by exchanging "incompleteness" and "ambiguity" wherever they appear in the description of their argument above. The substitution does not affect the plausibility of either argument.

\section{Involvement of a Lawyer}

Some courts apply hard-PER to a contract against a party that used a lawyer. ${ }^{45}$ This practice follows straightforwardly from the assumption that transaction costs are lower for sophisticated parties.

\section{Contemporaneous Negotiations}

Courts disagree over whether the parol evidence rule should apply to negotiations that occur at the same time that the contract is signed. Corbin argues that this problem is illusory since every negotiation is necessarily before or after the point in time at which a contract is entered. ${ }^{46}$ But this surprising bit of formalism overlooks the real problem. The question raised by the parol evidence rule is whether courts should treat extrinsic evidence of statements made

${ }^{45}$ See FARNSWORTH, supra note $2, \S 7.16$, at 548 (noting that courts place greater burdens on parties with greater bargaining power and drafting skill).

${ }^{46}$ See Arthur L. Corbin, The Parol Evidence Rule, 53 YALE L.J. 603, 618 (1944). 
immediately or a short time before the creation of the contract differently from extrinsic evidence of statements made a long time before the creation of the contract. A court could reasonably make a soft-PER exception to a general hard-PER rule for "contemporaneous" negotiations-that is, negotiations that occur shortly before the signing of the contract-on the ground that such evidence on average sheds more light on the meaning of the contract than evidence of earlier negotiations. Moreover, admission of "contemporaneous" evidence is less likely to cause judicial error than admission of stale evidence.

\section{Scrivener's Error}

Even the strictest adherents to hard-PER make exceptions for scrivener's errors. Critics of hard-PER sometimes argue that this exception shows the weakness of the argument for hard-PER: if extrinsic evidence reliably discloses scrivener's errors, it can reliably disclose that a term is unintended. However, the use of extrinsic evidence for the limited purpose of identifying scrivener's errors is not likely to create high expected error costs, and it eliminates the high transaction costs that would be necessary to proofread a writing with great care.

\section{A Note on the Canons of Interpretation}

Courts often rely on canons of interpretation, such as the injunction to interpret writings in a way that does not leave elements unexplained or superfluous, and the injunction to interpret the absence of an item as intended when the writing contains a list of similar items. Scholars scoff at these canons, and they are banal and do not affect the treatment of extrinsic evidence, but they do cohere with the discussion of extrinsic evidence so far. For example, drafters can more easily spot and correct glaring contradictions and omissions than more subtle defects in the writing. So a court pressed with an interpretation that creates a glaring contradiction or omission should hold that the interpretation is erroneous. Because the cost of spotting and correcting the contradiction is low, the court should assume that the parties did not consider it a contradiction and had another interpretation in mind. The relevant cost is not that of adding a promise to the writing, but that of revising the writing to correct mistakes. Otherwise the analysis is the same. 


\section{The Cost of Judicial Error}

In prior sections we assumed that the parties do not want courts to commit errors. This assumption perhaps seems obvious, but it is useful to explore in more detail how judicial error produces costs for parties.

Courts recognize that the parol evidence rule is related to the value of "commercial certainty." Courts that support hard-PER argue that this rule increases commercial certainty by enabling parties to predict the promises that courts will enforce. ${ }^{47}$ Courts that support soft-PER argue that soft-PER increases commercial certainty by allowing judges and juries to consider all relevant evidence. ${ }^{48}$ Few courts discuss the way each rule reflects a different tradeoff, ${ }^{49}$ and none that I know of has observed that the advantages of each rule relate to the tradeoff of transaction costs and judicial error, or to contractual complexity, conventionality, and value. However, by looking hard enough, it is possible to find cases in which, for example, the simplicity of the contract seems to cause a court to find an exception to the soft-PER that prevails in its jurisdiction..$^{50}$ One can also find cases in

${ }^{47}$ See, e.g., Wilson Arlington Co. v. Prudential Ins. Co., 912 F.2d 366, 369-70 (9th Cir. 1990) (barring parol evidence); Trident Ctr. v. Connecticut Gen. Life, 847 F.2d 564, 568-69 (9th Cir. 1988) (criticizing California law); Delta Dynamics, Inc. v. Arioto, 446 P.2d 785, 789 (Cal. 1968) (Mosk, J., dissenting) (criticizing the California rule); Masterson v. Sine, 436 P.2d 561, 570-71 (Cal. 1968) (Mosk, J., dissenting) (criticizing the majority's liberal interpretation of the parol evidence rule); Jake C. Byers, Inc. v. J.B.C. Investments, 834 S.W.2d 806, 811 (Mo. Ct. App. 1992) (emphasizing importance of enhancing predictability and discouraging perjury); Hatley v. Stafford, 588 P.2d 603, 606-07 (Or. 1978) (emphasizing importance of commercial certainty); id. at 610 (Lent, J., dissenting) (same).

${ }^{18}$ See the trio of soft-PER cases cited supra note 15.

${ }^{49}$ One example is Cole Taylor Bank v. Truck Insurance Exchange, 51 F.3d 736 (7th Cir. 1995). For scholarly discussion of these issues, see Robert Childres \& Stephen J. Spitz, Status in the Law of Contract, 47 N.Y.U. L. REV. 1, 8 (1972) (arguing for literal contract interpretation); Goetz \& Scott, supra note 11; Murray, supra note 3, at 1345-47 (arguing for a soft parol evidence rule); Edwin W. Patterson, The Intenpretation and Construction of Contracts, 64 COLUM. L. REV. 833, 846 (1964) (explaining how ambiguous contract terms may justify admitting parol evidence). However, with the limited exception of Goetz \& Scott, whose focus is elsewhere, none of the commentators analyzes the tradeoff in error costs produced by hard-PER and soft-PER, and little emphasis is put on contractual complexity.

${ }_{50}$ The California Supreme Court adopted a soft version of the parol evidence rule in 1968 in the trio of soft-PER cases cited supra note 15. Two years later, in Salyer Grain E Milling Co. v. Henson, $91 \mathrm{Cal}$. Rptr. 847 (Cal. Ct. App. 1970), which involved a contract to haul grain, the court excluded testimony that the shipper bore the risk of loss arising from an accident. Although the contract dealt with some other risk-allocation issues, it was silent on this one. Under soft-PER, a court would admit the extrinsic evidence since the contract appeared incomplete. However, the court argued that 
which a court finds an exception to hard-PER because of the conventionality of a contract. ${ }^{51}$ These cases are consistent with the model.

Courts rarely discuss why "commercial certainty"-that is, the reliable enforcement of promises-is valuable. The general answer to this question is that the prospect of judicial error encourages the promisor to engage in opportunism that reduces the gains from trade. This problem is discussed extensively elsewhere, ${ }^{52}$ but it is useful to show how it manifests itself in disputes involving the parol evidence rule.

Return to the example of the automobile sale. Seller's statements, $S$, provide information to Buyer about the product, such as its price, function, and quality. Through the process of negotiation, the parties refine their understandings of each other's interests. Later statements made by the Seller confirm or disclaim earlier statements. The contract contains those stipulations and disclaimers (set $C$ ); and some subset of these stipulations and disclaimers is put in writing (set W).

As suggested earlier, a court that follows hard-PER "errs" by excluding all of the statements in $W^{\prime}$, whereas the court that follows softPER errs by including some of the statements in $C^{\prime}$. These errors create two kinds of risks of opportunism. First, under hard-PER, Seller (in our example) can bias the court's interpretation of the con-

when an otherwise detailed contract, which covers closely related issues, does not allocate the risk of a particular contingency, and when that contract is negotiated by sophisticated parties, one should assume that the parties intended the loss to lie where it falls. See id at 852. The implication is that the absence of a term must be taken to be intended, so allowing in extrinsic evidence, ex post, creates the chance of judicial error, and, ex ante, requires the parties to undergo the costly process of predicting and disclaiming every possible judicial misinterpretation that could arise in the case of a dispute.

${ }^{51}$ In the early 1950s, Pennsylvania had an unambiguously hard-PER. See, e.g., Bardwell v. Willis, 100 A.2d 102 (Pa. 1953) (holding that if plaintiffs relied on any oral understanding or representations made prior to the execution of a written lease, they should have protected themselves by incorporating those promises into the written contract). But in Berger v. Pittsburgh Auto Equipment, 127 A.2d 334, 337 (Pa. 1956), the state supreme court admitted extrinsic evidence to show that an apparently unconditional lease of storage space in a building was (orally) conditioned on the floor being strong enough to hold the lessee's equipment. In this straightforward transaction, it must have seemed to the court that soft-PER's erroneous inclusion of extra-contractual statements was considerably less dangerous than hard-PER's erroneous exclusion of oral contractual statements. When transactions, such as this one, are routine, the danger of erroneous inclusion of terms is slight, so requiring parties to spell out every contingency serves no purpose.

${ }^{52}$ See, e.g., Timothy J. Muris, Opportunistic Behavior and the Law of Contracts, 65 MINN. L. REV. 521 (1981). 
tract in its favor if it can make statements in $W^{\prime}$ that the court properly excludes (i.e., unwritten statements), but on which Buyer mistakenly relies. Second, under soft-PER, Seller can bias the court's interpretation of the contract in its favor, if it can make statements in $C^{\prime}$ that the court erroneously includes (i.e., extra-contractual statements), on which Buyer does not rely. In both cases, Seller gains at Buyer's expense. The risk of such opportunism causes buyers to take costly precautions.

The first kind of opportunism is a standard concern in the literature on the parol evidence rule ${ }^{53}$ and is occasionally mentioned by courts. The usual case occurs when a merchant orally tells an unsophisticated consumer that the object for sale has desirable attributes that it in fact lacks. The writing, which is usually a complicated form, states that the merchant makes no representations as to the quality of the goods. Whether or not the writing also contains a merger clause, hard-PER would generally bar the court from admitting the evidence of the oral statement to vary the terms of the writing, leading consumers to take costly self-protective measures. Ex ante, merchants would like to commit themselves not to engage in this opportunism, but because consumers refuse to read writings, they cannot. Soft-PER is necessary to solve this problem and, indeed, courts in hard-PER jurisdictions sometimes depart from the rule when a consumer is involved. ${ }^{54}$

The second kind of opportunism has not been discussed in the literature or by the courts. Imagine that two sophisticated parties, following negotiations, reduce their deal to a writing. The writing contains a merger clause, but under soft-PER, courts might admit statements from $C^{\prime}$ to supplement or vary the terms of the writing. As a result, each party has an incentive to propose self-serving terms during the negotiations, even though each knows that the other party will reject the terms. The record of the self-serving terms creates a chance

${ }^{53}$ See, e.g., Murray, supra note 3, at 1372-89 (discussing standardized agreements and the parol evidence rule); Justin Sweet, Promissory Fraud and the Parol Evidence Rule, 49 CAL. L. REV. 877, 896 (1961) ("Promises made without the intention on the part of the promisor that they will be performed are unfortunately a facile and effective means of deception."); W. Richard West, Jr., Note, Chief Justice Traynor and the Parol Evidence Rule, 22 STAN. L. REV. 547, 563 (1970) (“[T] he results of a mechanistic protection of the written instrument are often harsh and unjust.").

${ }^{54}$ See, e.g., Rempel v. Nationwide Life Ins. Co., 370 A.2d 366, 370 (Pa. 1977) (stressing the vulnerability of consumers in insurance contracts); Mancini v. Morrow, 458 A.2d 580, 583 ( $\mathrm{Pa}$. Super. Ct 1983) (applying a relaxed interpretation of the parol evidence rule to the sale of a house). 
that a court under soft-PER will erroneously enforce those terms should a dispute arise. ${ }^{55}$

This kind of opportunism not only gives each party an incentive to state self-serving terms during the negotiations, but also gives each an incentive to insist on a more ambiguous writing, as well as an incentive to take costly self-protective measures, such as carefully monitoring and recording the course of the negotiations. The parties would prefer ex ante a regime in which they could commit themselves to relying only on the writing. The problem with soft-PER is that it hinders such a commitment. ${ }^{56}$

A related form of opportunism occurs when a party in a breach of contract suit seeks the enforcement of a promise that was intended as an extra-legal promise. An extra-legal promise is a promise made in conjunction with the explicitly contractual promises but that was not intended to be legally enforceable by the parties. Such promises occur because they are more effectively enforced through nonlegal sanctions, such as injury to reputation, than through judicial sanctions. Sometimes parties include extra-legal promises in the writing along with disclaimers-a practice that is reflected in the cases involving employment manuals. ${ }^{57}$ But parties also frequently use writings as

${ }^{35}$ Sometimes, a court suggests that hard-PER prevents fraud. If the court is not referring to fraudulent testimony (i.e., perjury), it might be referring to the opportunism problem. See, e.g., Big G Corp. v. Henry, 536 A.2d 559, 562 (Vt. 1987) (noting that the parol evidence rule forces contracting parties to understand that any contract terms and conditions not in the final writing are null and void).

${ }^{36}$ As a possible illustration, consider the Alabama case of Hurst $v$. Nichols Research Corp., 621 So. 2d 964 (Ala. 1993), in which a managerial employee sued the employer for failing to allow him to purchase as much stock (through stock options) as he had been promised. The written offer, to which the employee assented, specified a stock option less than the size discussed during negotiations. Despite a strong precedent supporting soft-PER, see Hibbett Sporting Goods, Inc. v. Biernbaum, 375 So. 2d 431, 436 (Ala. 1979) ("The question whether the parties have assented to a writing as a complete and accurate integration of their contract is ultimately one of intent and must be determined from the conduct and language of the parties and the surrounding circumstances."), the court affirmed the trial judge's refusal to admit the extrinsic evidence. One explanation for this result is that the court was seeking to penalize sophisticated employees for failing to disambiguate contractual negotiations. If the employee considered the more valuable stock option to be a decisive element of the contract, he should have made sure that the employer understood this. His failure to do so could at least be considered negligent, and, more germane, could be considered an attempt to obtain employment while maintaining a potential legal right to acquire higher pay than the employer believed he had offered.

${ }^{57}$ See, e.g., McDonald v. Mobil Coal Producing, Inc., 820 P.2d 986, 988 (Wyo. 1991) (finding that whether an employment manual altered employment-at-will contract terms was a genuine issue of material fact). 
a means of distinguishing legal promises, which are included in the writing, from extra-legal promises, which are excluded from the writing. Allocating promises between the oral and the written is a cheap and convenient way for parties to distinguish extra-legal and legal promises. 58

It is tempting to argue that soft-PER interferes with the parties' ability to maintain the extra-legal component of their relationship. By blurring the correspondence between oral representation and extra-legality, on the one hand, and the correspondence between written representation and enforceability, on the other, soft-PER interferes with the use of nonlegal enforcement mechanisms to maximize the value of trading relationships. ${ }^{59}$ Although soft-PER may cause parties to substitute to nonlegal enforcement by increasing the cost of using writings to identify legal promises, this substitution may either increase or decrease joint welfare. As the details of this argument are complex, they are placed in an appendix.

\section{E. Further Economic Considerations}

It is worth considering a few other arguments that have been made in support of, or in opposition to, the parol evidence rule. These arguments appear in opinions now and again, but either are versions of the arguments I have been discussing or are not plausible.

The first of these arguments is that hard-PER is valuable for promoting judicial efficiency. Courts can more easily evaluate written contracts than oral contracts. Presumably, writings serve as more reliable evidence than does testimony regarding oral contracts, because (1) the testimony depends to a greater extent on memory, and memory is fallible; and (2) the testimony depends to a greater extent on honesty, and witnesses have an incentive to be dishonest. By en-

${ }^{53}$ Cf. Jason Scott Johnston, The Statute of Frauds, in THE NEW PALGRAVE DictionaRY OF ECONOMICS AND LAW (Peter Newman ed., forthcoming 1998) (arguing that the Statute of Frauds enables parties to signal whether their promises are to be legally enforceable).

${ }^{59}$ Compare the collective bargaining case discussed earlier, Bidlack $v$. Wheelabrator Corp., in which Judge Easterbrook suggests that extra-contractual promises serve as a flexible basis for post-contractual behavior in light of changed circumstances, a function that is defeated if courts enforce such promises as though they were part of the contract. See 993 F.2d 603, 618 (7th Cir. 1993) (en banc) (Easterbrook, J., dissenting). Standard works on extra-contractual promises include Benjamin Klein \& Keith B. Leffler, The Role of Market Forces in Assuring Contractual Performance, 89 J. POL. ECON. 615 (1981), and Lester Telser, A Theory of Self-Enforcing Agreements, 53 J. Bus. 27 (1980). 
couraging parties to use writings, the parol evidence rule facilitates judicial evaluation of the dispute. ${ }^{60}$

There are two problems with this argument. First, there is no reason to believe that the judicial savings are significant, or that they are worth the disruptions in business practices that result from forcing people to formalize their contracts. Second, the parol evidence rule does not encourage parties to use writings so much as it encourages them to use complete writings rather than partial writings. Hard-PER may cause parties to revert to oral contracts rather than to more complete written contracts. Most importantly, judicial accuracy is not independently valuable; it is valuable only to the extent that it increases the value of contracts.

A related argument is that hard-PER is valuable for protecting third parties from fraud. The classic justification for the Statute of Frauds is that it discourages wrongdoers from trying to convince courts that some third party owes them a contractual obligation. ${ }^{61}$ The parol evidence rule extends this policy to relations between two contracting parties. It discourages a promisee from claiming that a promisor orally made promises that were in fact never made. This is a valid argument, but it is difficult to evaluate its implications. Granting the problem, one can still quarrel about whether hard-PER protection is necessary or whether soft-PER is sufficient.

Another argument occasionally presented in support of hard-PER is that it allows judges to control juries by preventing them from hearing extrinsic evidence. The concern is that if juries considered all of the extrinsic evidence, rather than just the writing, they would not render good judgments. ${ }^{62}$ This argument might have historical support, but as a normative argument it is unconvincing. If juries are incompetent, why would limiting them to certain kinds of evidence lead to a more accurate result? If the argument is that the writing is more reliable, so that juries, despite their inadequacies, would be more likely to render a correct result, then the argument is indistinguishable from the judicial efficiency argument, discussed above. The jury-control argument derives its minimal plausibility from the

${ }^{60}$ See Childres \& Spitz, supra note 49 , at 8 (arguing that strict adherence to the parol evidence rule is supported by "considerations of administrative convenience").

${ }^{61}$ See Eric A. Posner, Norms, Formalities, and the Statute of Frauds: A Comment, $144 \mathrm{U}$. PA. L. REv. 1971, 1977 (1996) (discussing justifications for the Statute of Frauds).

${ }^{62}$ See McCormick, supra note 17, at 366 ("The average jury will, other things being equal, lean strongly in favor of the side which is threatened with possible injustice and certain hardship by the enforcement of the writing."). 
unarticulated premise that extrinsic evidence biases juries toward poorer, weaker consumers and away from crafty merchants, so that juries would not resolve the dispute in a neutral way. This brings us to a final argument.

The final argument suggests that hard-PER prevents juries from biasing their decisions toward poor people or consumers, in violation of contractual expectations. ${ }^{63}$ Hard-PER thus allows judges to exclude any extrinsic evidence that juries could use to justify biasing contractual interpretation in favor of the consumer. This argument assumes that the parol evidence rule is most commonly invoked in cases in which customers sign writings without reading or understanding them, after being swayed by earlier oral promises by the merchant. ${ }^{64}$ This argument hardly supplies an attractive normative justification for the parol evidence rule. If juries systematically refuse to enforce the law, this suggests either that juries correctly believe that the law is bad, and therefore the law should be changed, or that juries incorrectly believe that the law is bad, and therefore the jury system should be changed.

This argument in favor of hard-PER is regarded by some as a stronger argument against using hard-PER. According to this theory, the abolition of the parol evidence rule would benefit consumers because the rule allows merchants to mislead consumers by making oral representations that are inconsistent with the writings. This argument is discussed in Part II.C.1, above.

\section{CORBIN'S ARGUMENT}

We should spend a moment considering Corbin's argument in favor of soft-PER, because it has been influential. Corbin believed that the supporters of the parol evidence rule overestimated the determinateness of written words. In fact, Corbin argued, the meaning of a word depends on its context, ${ }^{65}$ so the parol evidence rule should not

${ }^{63}$ See id. at 368 (asserting that without a firm rule, a jury will make its decision out of "sympathy for a party whom the shoe of the written contract pinches").

${ }_{64}$ In Pennsylvania, however, the initial move toward soft-PER occurred before any consumer parol evidence rule cases reached the state supreme court. See supra notes 12-14. Similarly, none of the three famous California cases decided by Justice Traynor involved consumers. See supra note 15.

${ }_{65}$ Philosophy of language distinguishes between semantic and pragmatic meanings of a word; the former are invariant with respect to context, the latter are not. See Michael S. Moore, A Natural Law Theory of Interpretation, 58 S. CAL. L. REv. 277, 288-91 
be used to downgrade evidence of context. ${ }^{66}$

Williston, the chief defender of the strict version of the parol evidence rule, never revealed his linguistic presuppositions. Judges occasionally have dropped statements about the nature of language, but more as flourishes on a conventional doctrinal argument than as part of a mature theoretical argument. Corbin was thus not attacking any particular existing theory when he wrote. He must have assumed that a supporter of hard-PER is compelled to assume that the meaning of words does not depend on context.

Corbin cannot have meant that language is indeterminate. The parol evidence rule does not privilege language over something else; it privileges some language (the final writing) over other language (earlier written and oral statements). ${ }^{67}$ If language were completely indeterminate, a rule that allowed a court to consider all relevant messages (i.e., pieces of extrinsic evidence) would not produce any more accurate or determinate a result than a rule that allowed a court to consider only some messages.

When Corbin argues that meaning depends on context, he seems to mean that the more context admitted as evidence, the better are the court's chances of discovering the meaning of the contract. The parol evidence rule permits the admission of extrinsic evidence only

(1985). Under a charitable reading of Corbin's argument, Corbin assumes (plausibly) that the pragmatic aspect of meaning dominates when courts interpret contracts.

${ }^{66}[\mathrm{~N}] \mathrm{o}$ man can determine the meaning of written words by merely glueing his eyes within the four corners of a square paper; ... that it is men who give meanings to words and that words in themselves have no meaning; and ... that, when a judge refuses to consider relevant extrinsic evidence on the ground that the meaning of written words is to him plain and clear, his decision is formed by and wholly based upon the completely extrinsic evidence of his own personal education and experience.

Corbin, supra note 17, at 164. Corbin's analysis draws on that of Wigmore. See 9 JOHN HENRY WIGMORE, EVIDENCE IN TRIALS AT COMMON LAW \$2400, at 6 (James H. Chadbourn ed., 1981) (" $[A]$ writing has no efficacy per se, but only in consequence of and dependence upon other circumstances external to itself."). For updated versions of this argument, see STANLEY FISH, THERE's No SUCH THING AS FREE SPEECH AND IT'S A GOOD THING, TOO 144-56 (1994); Walter Benn Michaels, Against Formalism: The Autonomous Text in Legal and Literary Interpretation, 1 POETICS TODAY 23 (1979). This also seems to be the thrust of Traynor's claim that the parol evidence rule is based on a belief that "perfect verbal expression" is possible, a belief that "is a remnant of a primitive faith in the inherent potency and inherent meaning of words." Pacific Gas \& Elec. Co. v. G.W. Thomas Drayage \& Rigging Co., 442 P.2d 641, 643-44 (Cal. 1968) (en banc) (footnote omitted).

${ }^{67}$ See, e.g., Olivia W. Karlin \& Louis W. Karlin, The California Parol Evidence Rule, 21 Sw. U. L. REV. 1361, 1378-79 (1992) (discussing the "inherently contradictory" nature of Corbin's argument for allowing extrinsic evidence in contract interpretation). 
after the judge determines that the writing is ambiguous or incomplete, but a judge can determine that a writing is ambiguous or incomplete only if he or she knows the commercial context to which the writing refers. The word "chicken," for example, is precise in a contract between a seller who has only one chicken and a buyer who has agreed to buy it; but it is ambiguous in a contract signed by a buyer and a seller who are dealers in an industry that distinguishes between kinds of chicken which are routinely bought and sold, including fryers and roasters. A court cannot determine whether "chicken" is ambiguous without first looking at parol evidence of trade custom and the parties' dealings; having done so, it has already violated the parol evidence rule. ${ }^{68}$ One can imagine that if judges strictly obeyed the parol evidence rule, their decisions in a case such as this would depend on their personal knowledge. A judge who happens to know something about the chicken industry-perhaps because of his past experience as a commercial lawyer-will believe that the word "chicken" is ambiguous; a judge who knows nothing about the industry will believe that the word "chicken" is unambiguous. The parol evidence rule excludes extrinsic evidence from consideration, while allowing the judge to rely on his or her personal knowledge, even though the former, more so than the latter, would enable the court to determine the parties' intentions.

Corbin's mistake is that, in assuming that the purpose of contract law is to enforce the intentions of the parties, he overlooks the fact that the parties, in addition to their ordinary contractual intentions, have intentions about how courts should evaluate their contract in case of a dispute. To Corbin, the parol evidence rule looks like an arbitrary barrier to the enforcement of these ordinary contractual intentions, rather than a device for furthering them. ${ }^{69}$ In fact, the

${ }^{63}$ See Michaels, supra note 66, at 25-27 (discussing Frigaliment Importing Co. v. B.N.S. Int'l Sales Corp., 190 F. Supp. 116 (S.D.N.Y. 1960)).

${ }^{69}$ The cardinal rule with which all interpretation begins is that its purpose is to ascertain the intention of the parties. The criticized [parol evidence] rule, if actually applied, excludes proof of their actual intention. It is universally agreed that it is the first duty of the court to put itself in the position of the parties at the time the contract was made; it is wholly impossible to do this without being informed by extrinsic evidence of the circumstances surrounding the making of the contract.

Corbin, supra note 17, at 162 . Corbin mistakenly assumes that the parties' intentions cannot also include a preference against judicial evaluation of extrinsic evidence, a preference based, one supposes, on the parties' prediction of whether extrinsic evidence is more likely to mislead judges or inform them. Traynor repeats Corbin's error in his influential opinion criticizing the plain.meaning rule. See Pacific Gas E Elec., 442 
parties derive advantage from being able, in their contract, to limit the evidence a court can use to decide a dispute should one arise, just as they derive advantage from being able, in their contract, to choose the forum in which disputes will be resolved. The attractiveness of hard-PER for this purpose-and the evidence that it is not arbitraryis shown by the frequency with which parties use merger clauses. ${ }^{70}$ Although parties do fail to include merger clauses from time to time, they do not, as far as I know, include "anti-merger" clauses that explicitly ask courts to look at extrinsic evidence. Yet if Corbin were right, at least some sophisticated parties would agree with him and include "anti-merger" clauses in their contracts, particularly in jurisdictions that have a strict parol evidence rule.

In legal disputes, the context is determined by the rules of evidence. The judge and jury look at all evidence relevant to the facts in dispute. Contractual disputes are unique because the parties can, in advance, specify the relevant context. This is important, because the parties know in advance that judges err, and can evaluate this risk in light of their contractual objectives and structure the contract in a way that minimizes this risk. ${ }^{71}$ The parol evidence rule can thus be understood as a device for allowing parties to choose the appropriate context. The parties estimate the likelihood that a court looking back at their contract will be misled by extrinsic evidence reflecting the context, and they, in effect, signal to the court the context which they think would be ideal, whether it be writing alone or writing plus extrinsic evidence. As an example, one might expect the parties to signal the courts to ignore the context when the writing has been preceded by complex preliminary negotiations during which the parties made a host of promises they no longer want enforced.

P.2d at 644 (stating that the plain meaning rule "either den[ies] the relevance of the intention of the parties or presuppose[s] a degree of verbal precision and stability our language has not attained"). Fish and Michaels also repeat this error. See FISH, supra note 66, at 146; Michaels, supra note 66, at 28-29.

${ }^{70}$ I have not tried to do systematic research on the frequency with which sophisticated parties use merger clauses, but it is clear that they are extremely common. Examples can be found among the form contracts reproduced in JOHN F. DOLAN, UNIFORM COMMERCIAL CODE: TERMS AND TRANSACTIONS IN COMMERCIAL LAW (1991). See, e.g., id. at 31 (K Mart's order contract); id. at 79 (Chrysler's sales and service agreement with dealers); id. at 121 (Unisys equipment lease); id. at 198 (Michigan National Bank business loan agreement); id. at 275 (Michigan National Bank purchase of chattel paper); id. at 281 (Michigan National Bank aircraft security agreement).

${ }^{7}$ Cf. Gillian $\mathrm{K}$. Hadfield, Judicial Competence and the Interpretation of Incomplete Contracts, 23 J. LEgal STUD. 159, 163 (1994) (discussing the concept of judicial error in the context of contractual incompleteness). 
Still, perhaps this argument does not represent Corbin's views fairly. Corbin could be understood to say the following: The set $H$ of promises enforced under hard-PER is a function both of the writing and the general interpretive rules used by courts, including rules for implying terms and the courts' prejudices about the form and purpose of typical business transactions. The scope of every term in $W$ is not self-defining, but depends on the linguistic practices of the parties. $^{72}$ In order to interpret these terms, courts must either rely on their own linguistic practices or make judgments about the parties' linguistic practices. The set $G$ of promises enforced under soft-PER is a function both of the writing and the extrinsic evidence as interpreted in light of the judges' commercial prejudices and linguistic practices.

Thus, whereas the analysis in Part I assumes that $H$ is more sensitive to the contents of the writing than $G$ is, it is clear that under both regimes the courts' use of the writing will be mediated by elements outside the control of the parties: the general interpretive rules, the court's prejudices under hard-PER, and the extrinsic evidence as interpreted in light of the courts' prejudices under soft-PER. It is possible that the influence of these mediating elements on the courts' behavior dwarfs the impact of the writing, in which case the practical distinction between hard-PER and soft-PER is nil.

All of this is possible. But because the principles governing the implication of terms and the general interpretive principles are invariant with respect to the facts of contractual negotiation, parties should be able to take account of these principles when negotiating their contract and predicting judicial enforcement under hard-PER. Because judges are appointed or elected from a homogenous group of people, and because their interpretive prejudices are revealed in their decisions and opinions, these prejudices should be relatively predictable at the time of contracting. But parties cannot know in advance the effect of extrinsic evidence on judicial decisions under soft-PER, because each party cannot know in advance what the other party might introduce as extrinsic evidence-which excerpts from the general chit-chat or which pages of scrawled notes-should a dispute arise.

Corbin's argument is, at its core, based on a skepticism about the capacity of formalities to restrain courts and render their judgments

${ }^{72}$ See David Charny, Hypothetical Bargains: The Normative Structure of Contract Interpretation, 89 MICH. L. REV. 1815, 1856 (1991) (discussing interpretive issues). 
predictable. If he is right, then talk of the differing effects of soft-PER and hard-PER is idle, but so too is talk of the advantages and disadvantages of any doctrine of contract law.

\section{CONCLUSION}

This Essay has made an argument about the conditions under which stricter and weaker parol evidence rules are consistent with a value-maximizing contract law. The normative implications of the argument are limited, however, because it is difficult to measure the variables on which the value of the parol evidence rule depends. But the argument does tell a unifying story, a story that, pace Corbin and others, shows that the parol evidence rule serves straightforward functions and coheres with a large number of contract law doctrines. Although nothing in the argument compels a jurisdiction to choose one parol evidence approach over the other, the argument supplies a coherent way of thinking about the parol evidence rule that, if followed, will promote doctrinal consistency regardless of which general approach is taken.

The discussion has implications beyond the issue of the treatment of extrinsic evidence. For contract law, the discussion sheds light on old debates about the optimal tailoring of default rules, emphasizing the decisive roles of judicial competence and transaction costs. The discussion also has implications for statutory analysis. The use of extrinsic evidence to interpret written contracts is analogous to the use of legislative history in statutory interpretation. This analogy, of course, has been pursued in earlier writings about statutory interpretation, but those writings relied on now-dated theories of contract interpretation.

The discussion suggests that the use of legislative history for the purpose of interpreting statutes should depend, among other things, on judicial competence and the "transaction costs" of reducing legislative negotiations to a written statute. Judicial competence varies from state to state and from country to country; it may be poor, for example, in developing nations. Thus, the analysis suggests that the optimal form of legislative interpretation will vary among jurisdictions. Transaction costs vary with the complexity and novelty of legislation. Legislative history may, for example, be less justified for interpreting incremental modifications of existing legislation than for interpreting statutes that generate an entirely new set of legal rights and entitlements or administrative machinery. 


\section{APPENDIX}

One argument in favor of hard-PER is that it reduces the cost of using a writing in order to obtain an enforceable contract. If, however, parties rely on both legal and nonlegal sanctions for the enforcement of contracts, reduction in the cost of a writing does not necessarily increase the ex ante value of contracting. The reason is that the reduction in the cost of legal enforcement may cause parties to substitute from nonlegal enforcement to legal enforcement even when nonlegal enforcement remains cheaper overall. This Appendix sketches a model demonstrating this point.

Suppose there are two types of sellers, "high types" $\left(S_{H}\right)$ and "low types" $\left(S_{L}\right)$, with high types constituting a fraction, $q$, of the population of sellers. High types value future gains more than low types do. Buyers cannot distinguish sellers by type. A seller makes an oral offer to sell a widget for a certain price. A buyer $(B)$ then chooses among: (1) rejecting the offer, in which case payoffs are zero for both parties; (2) accepting the offer orally; and (3) accepting the offer on the condition that the seller supplies a writing that meets the requirements for a legally enforceable contract. The oral contract is not legally enforceable; the written contract is legally enforceable to the extent that performance is verifiable by courts. Unless the buyer rejects, the seller then either "cooperates" or "cheats." These terms are defined in the following way. To cooperate is to perform the contract in a way that exceeds legal requirements-for example, delivering before deadline, forgiving a late payment, or providing unusually high quality goods, as sellers often do for their best customers. To cheat is to do as little as is legally required, which means either (a) not performing if the contract is legally unenforceable, or (b) performing in a crabbed and literalistic way if the contract is legally enforceable. More precisely, suppose that the optimal contract contains some terms whose performance can be verified by courts but other terms whose performance can be observed only by the parties: then to cheat on a written contract means to perform only verifiable valuemaximizing actions, whereas to cooperate means to perform both verifiable and observable value-maximizing actions.

$B$ receives $v$ if $S$ performs literalistically (that is, cheats on a writing); $d v$ if $S$ cooperates ( $d>1$ ); and $-r$ if $S$ fails to perform (that is, cheats on an oral contract). It is assumed that $B$, rather than $S$, absorbs the cost.of the writing, $w$, but nothing turns on this assumption. $S$ receives $p$ if $B$ accepts and $S$ cooperates. This amount is multiplied 
by $a$ if $S$ is a high type and $B$ accepts orally ( $a>1$ ). This multiplier represents the discounted long-term gain from future business. It is assumed that if $S$ cooperates, that is, treats $B$ well during the transaction-by performing at a level beyond the requirements of the writing- $B$ will more likely take future business to $S$ than if $S$ performs merely adequately. But only $S_{H}$ gains from the expected future business. $S_{L}$ does not benefit from the multiplier, because $S_{L}$ does not care about future payoffs. It is assumed, for reasons given below, that if $B$ demands a writing, $S_{H}$ cannot obtain long-term gains by cooperating. Either type of seller gains $b p$ if she cheats $B$ on a writing, $b>1$, but $b<a$. This reflects the fact that a seller does better by cheating than by cooperating if there are no future consequences, but the high type of seller gains even more by establishing a long-term relationship with the buyer. Either type of seller gains $c p$ if she cheats $B$ on an oral contract, where $a>c>b$. A seller saves money by performing in a literalistic way, rather than in a value-maximizing way; she saves more if she can refuse to perform than if she performs literalistically, but the high seller would rather lose the short-term gains from cheating than lose future business.

Return to the assumption that if $B$ demands a writing, $S_{H}$ will not obtain long-term gains from cooperating. This assumption is based on the intuition, which is not modeled, that by demanding a writing, $B$ signals to $S_{H}$ that $B$ does not trust $S_{H}$, in which case $S_{H}$ would be reluctant to incur the costs of entering a long-term relationship. To model this intuition, one would have to assume that there are two types of $B$, a high type and a low type, and only $B_{H}$ gains from a longterm relationship with $S_{H}$. $S_{H}$, then, would want to initiate such a relationship, through cooperating, only if she believed that the buyer belonged to the high type. $B_{H}$ would signal his type by declining to demand a writing, thus exposing himself to opportunism, while $B_{L}$ would demand a writing. Given that only a $B_{L}$ would demand a writing, $S_{H}$ would not cooperate with someone who demanded a writing. This additional assumption is realistic, because the problem of demonstrating trust is usually two-sided, but incorporating it in the model would produce great complexities, and it is best left to future work.

There are three equilibria of interest. In the distrust equilibrium, $B$ demands a writing, and $S_{i}$ cheats the buyer. The buyer does not deviate, if $v-w>-r$. (Actually, $v-w>0$; if $v-w<0$, then, as described below, a reject equilibrium will obtain.) Given that the seller will cheat, the buyer should protect himself with a writing. The seller (either type) does not deviate if $b p>p$, which is true by assumption. Given that the 
buyer will demand a writing and therefore cannot be trusted, $S_{i}$ will cheat.

In the trust equilibrium, $B$ accepts orally; $S_{H}$ cooperates; $S_{L}$ cheats. $B$ does not deviate if $(q d v+(1-q)(-r))>v-w$, that is, $w>(v-q d v+(1-q) r)$. Given that $B$ gains more from cooperating with $S_{H}$ than he loses from being cheated by $S_{L}$, relative to his payoff in the distrust equilibrium, $B$ does better by accepting orally. $S_{H}$ does not deviate if $a p>c p$, which is true by assumption. $S_{L}$ does not deviate if $c p>p$, which is true by assumption. $S_{H}$ prefers the long-term relationship that can be achieved through cooperation; $S_{L}$ prefers the gains from cheating.

In the reject equilibrium, $B$ rejects $S_{i}^{\text {'s }}$ offer. In the distrust equilibrium $B$ would receive $v-w$; in the trust equilibrium $B$ would receive $q d v+(1-q)(-r)$. If $w>v$ and if $((1-q)(r))>q d v$, then $B$ would be better off receiving 0 . So $B$ rejects regardless of what $S$ would do. When writings are expensive and the expected loss from dealing with $S_{L}$ is sufficiently high, $B$ rejects all offers.

To see the effect of the parol evidence rule, imagine that a trust equilibrium exists. Notice that $B$ accepts orally only as long as the cost of the writing is sufficiently high. If the cost of the writing declines sufficiently, to $w^{\prime}<w$, as it might if soft-PER were converted to hard-PER, then $B$ would deviate. The new equilibrium would be a distrust equilibrium. $B$ 's new payoff is $v-w^{\prime}$ and $S_{i}^{\prime}$ s payoff is $b p$. This is a gain to $B$ of $v-w^{\prime}-q d v+(1-q) r$. $S_{H}$ 's payoff falls from $a p$ to $b p$; and $S_{L}$ 's payoff falls from $c p$ to $b p$. So the reduction in the cost of the writing causes an aggregate loss if $\left(v-w^{\prime}-q d v+(1-q) r\right)<((a+c-2 b) p)$.

This result shows that a shift from soft-PER to hard-PER can reduce aggregate wealth. As noted above, an important step lies outside the model: When $B_{H}$ demands a writing to protect himself against exploitation by an $S_{L}, S_{H}$ can no longer distinguish a $B_{H}$ from a $B_{L}$. In the model, then, $S_{H}$ will cheat if $B$ demands a writing. $B$ accepts orally if the value of the trust relationship with $S_{H}$ exceeds the cost of being exploited by $S_{L}$, given the cost of using a writing to protect himself. As the cost of using a writing declines, however, protection against $S_{L}$ becomes more attractive, until $B$ prefers it to the longterm relationship with $S_{H}$. In making this move, $B$ does not take account of the costs to $S_{i}$, in particular, the cost to $S_{H}$ from losing the ability to enter long-term contracts.

There are many problems with this argument, which can be resolved only with a more complicated model. Therefore, the argument should be taken as conjecture only. If the argument is correct, it has significance beyond the question of the optimal parol evidence 
rule. If nonlegal enforcement of contracts is significant, then a reduction in the cost of using the legal system can make parties worse off. This has importance for debates about rules and standards, formalities, and other issues of legal process, where the usual assumption is that reducing the cost of the legal system makes all parties better off. 
